\title{
Portrait of the North West
}

\author{
By Rachel Young and Frances Sly, Office for National Statistics
}

\section{Key points}

- The North West has a population of 6.9 million, the third greatest among the regions of England and countries of the UK, with only London and South East having higher populations

- The region's population is projected to increase at the lowest rate of all the English regions (9 per cent between 2008 and 2033) and is one of two regions where the working-age population is projected to decrease

- Over 87 per cent of the population live in urban areas, contributing to the highest regional population density in the UK outside London

- The Lake District National Park occupies 18 per cent of the land area of the North West region

- The North West has the second highest rainfall in England

- The North West makes a larger contribution to the UK's manufacturing industry than any other region (13 per cent of manufacturing gross value added in 2008)

- The North West has the third largest expenditure on research and development by businesses in the UK. Almost 78 per cent of the region's total research and development expenditure was in businesses, the second highest proportion of any region in the UK

- Of the 939 sites in England generating electricity from renewable sources in 2009, 150 were in the North West (16 per cent) - more than any other English region

- In the North West, 47 per cent of motor vehicle traffic on major roads was on motorways, the highest proportion among the English regions

\section{Introduction}

The North West region covers 14,100 square kilometres (sq km) and is the fourth smallest region in England after London, North East and West Midlands. However, in population terms it is the third largest with 6.9 million people. The region covers 11 per cent of the total area of England and 6 per cent of the UK. Over 87 per cent of the population live in urban areas, contributing to the second highest regional population density in the UK, 489 people per sq $\mathrm{km}$, compared with London at 4,932 people per sq $\mathrm{km}$.

Two conurbations, Manchester and Merseyside, span the region with Cheshire to the south and Lancashire and Cumbria to the north. Cumbria is largely rural with approximately 0.5 million residents living in $6,800 \mathrm{sq} \mathrm{km}$, equivalent to 73 people per sq $\mathrm{km}$. In comparison, Merseyside has approximately 1.4 million residents living in $645 \mathrm{sq} \mathrm{km}$, equivalent to 2,100 people per sq $\mathrm{km}$. 
The region has a long western coastline facing the Irish Sea, running from its border with Scotland in the north to North Wales in the south. To the east, the Pennine Hills separate it from the North East, and Yorkshire and The Humber regions (see Map 1).

\section{Map $1 \quad$ North West: physical features}

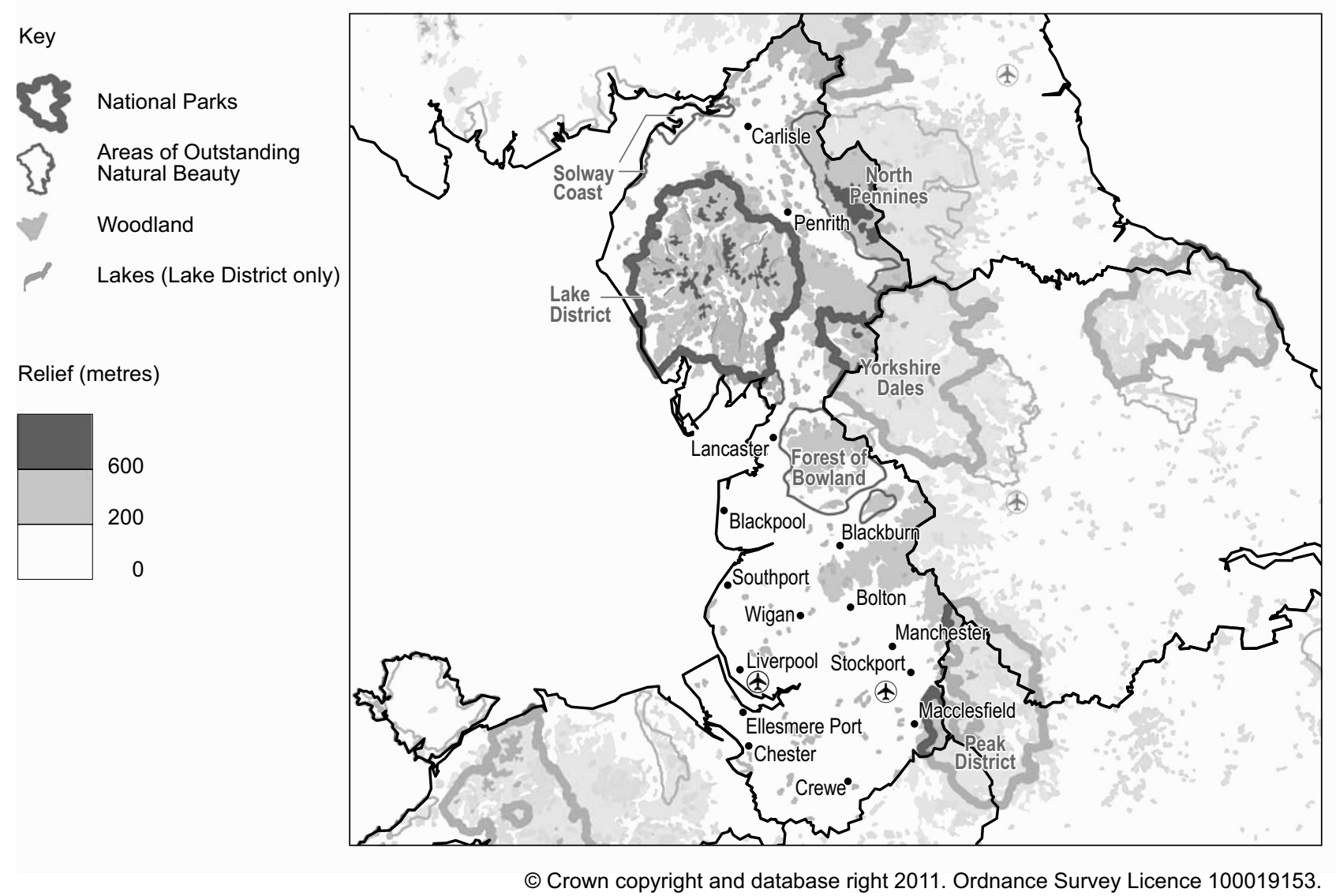

Administratively, the region comprises two counties (Cumbria and Lancashire), 6 unitary authorities, and 15 metropolitan districts within the metropolitan counties of Greater Manchester and Merseyside. Two of the unitary authorities - Chester and Cheshire West, and Cheshire East were created in 2009 from the districts of the former county of Cheshire. Between them the two remaining counties contain 18 districts (see Map 2).

The region is easily accessible from the north and the south via the M6 and the West Coast mainline railway between London and Edinburgh; from east to west, the M62 connects Liverpool to Leeds. There are two major international airports in the region; in 2008 Manchester handled 21.0 million passengers and Liverpool 5.3 million. The North West also has a major seaport in Liverpool, which handled 5 per cent of all UK sea freight in 2008 (32.2 million tonnes).

The North West makes a relatively larger contribution to the manufacturing industry than any other region or country of the UK. North West manufacturing generated an estimated turnover of $£ 63.3$ billion in 2008. 


\section{Map 2 North West: local or unitary authority ${ }^{1}$, NUTS $2^{2}$ sub-regions and Rural/Urban Definition ${ }^{3}$}

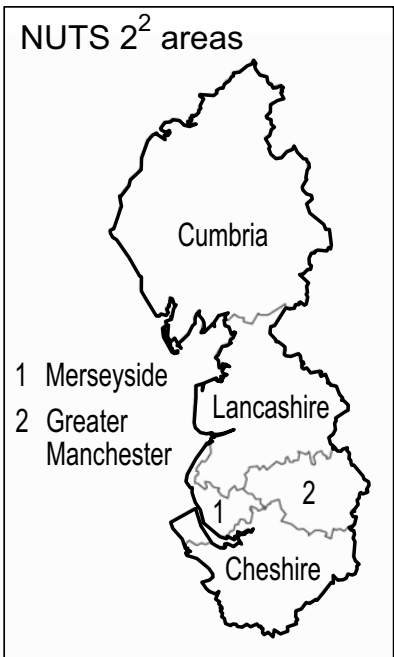

8

Ln Local or unitary authority 1 boundary

- NUTS 2 boundary ${ }^{2}$

\section{Rural/Urban Definition ${ }^{3}$}

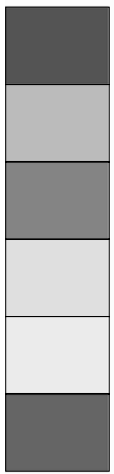

Urban population over 10,000-Less Sparse

Urban population over 10,000-Sparse

Town and FringeLess Sparse

Town and FringeSparse

Village, Hamlet and Isolated Dwellings - Less Sparse

Village, Hamlet and Isolated Dwellings- Sparse

$\begin{array}{ll}1 \text { Blackpool UA } & 13 \text { Wigan } \\ 2 \text { Preston } & 14 \text { Bolton } \\ 3 \text { South Ribble } & 15 \text { Bury } \\ 4 \text { Chorley } & 16 \text { Rochdale } \\ 5 \text { Blackburn with Darwen UA } & 17 \text { Salford } \\ 6 \text { Hyndburn } & 18 \text { Trafford } \\ 7 \text { West Lancashire } & 19 \text { Manchester } \\ 8 \text { Rossendale } & 20 \text { Oldham } \\ 9 \text { Sefton } & 21 \text { Tameside } \\ 10 \text { Liverpool } & 22 \text { Stockport } \\ 11 \text { Knowsley } & 23 \text { Warrington UA } \\ 12 \text { St. Helens } & 24 \text { Halton UA }\end{array}$

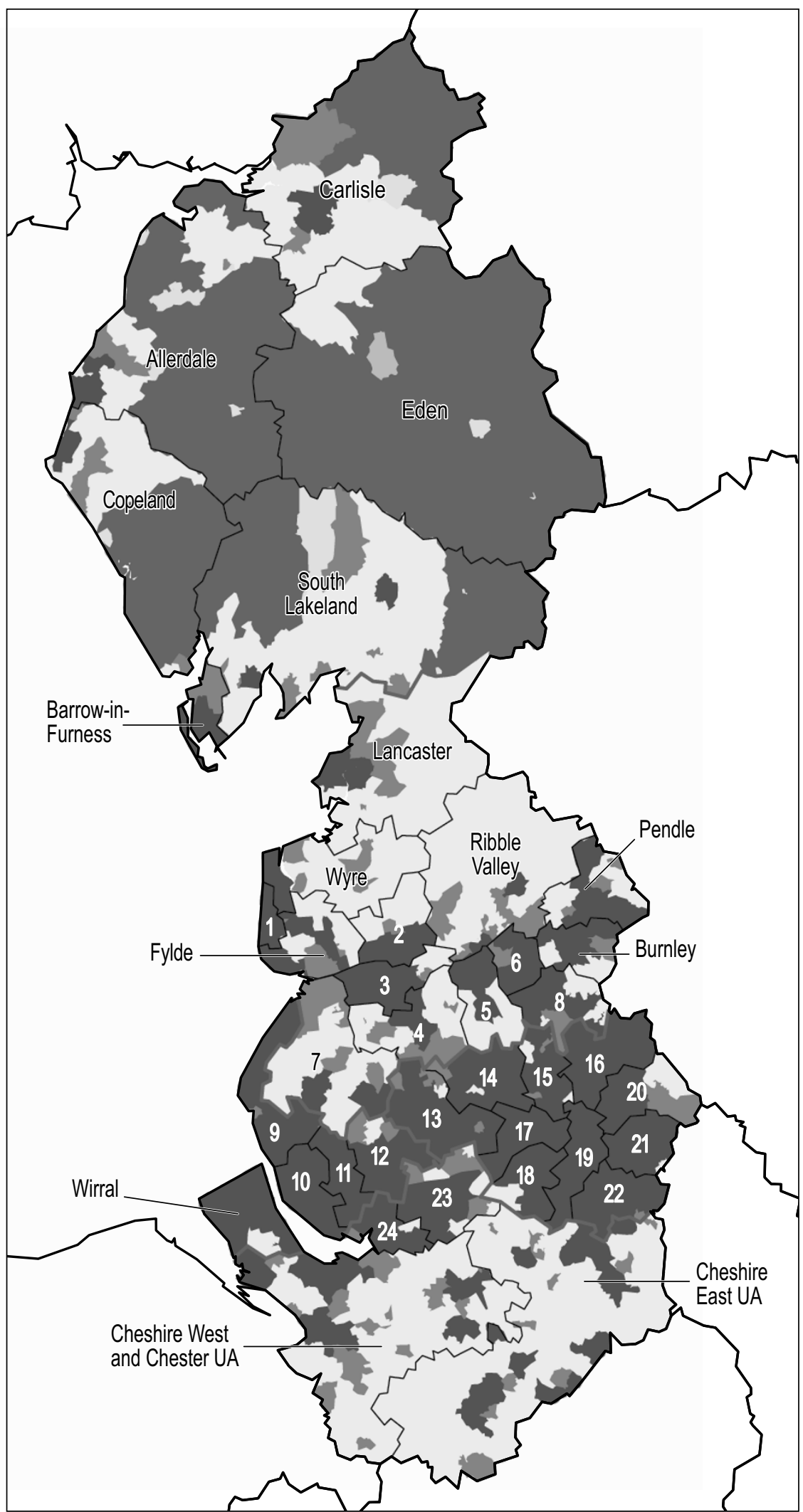

(c) Crown copyright and database right 2011. Ordnance Survey Licence 100019153.

1 After the April 2009 re-organisation.

2 Nomenclature of Units for Territorial Statistics, level 2.

3 By Lower Layer Super Output Area. 
Over 250,000 businesses (registered for VAT and/or PAYE) operate in the North West, with a quarter of businesses in the 'retail' and 'professional, scientific and technical' industries. North West enterprises make the third largest expenditure on research and development by businesses in the UK. Almost 78 per cent of the region's total research and development expenditure was by businesses, the second highest proportion of any region of England or country of the UK.

The North West receives 13 million trips from UK residents, with around a tenth of the UK total number of tourist nights being spent there. The region also has the fourth highest number of nights spent by overseas tourists in 2008. Tourists spent $£ 3.2$ billion in the North West in 2008. The most popular paid attractions in the region are Windermere Lake Cruises, Chester Zoo, Tatton Park and Blackpool Tower and Circus. Among UK towns and cities, Manchester had the third highest number of visits from overseas residents and Liverpool had the sixth highest. The North West is also well-known for the locations for numerous soap operas, such as Hollyoaks (Chester), Brookside (Liverpool) and the longest running soap opera Coronation Street (Manchester), which celebrated its fiftieth birthday in December 2010.

The North West contains the Lake District National Park, representing 18 per cent of the region's land area. The National Park features the highest mountain in England (Scafell Pike) and the largest lake (Windermere). It also includes 11 per cent of the land that lies within Areas of Outstanding Natural Beauty in England and $6 \mathrm{~km}$ of the Heritage Coast. The two conurbations are surrounded by Green Belt land, representing 19 per cent of the region's total land area. There are over 400 Sites of Special Scientific Interest and a cultural World Heritage Site, Liverpool Maritime Mercantile City. Liverpool was designated European Capital of Culture in 2008.

In 2009, the region had the highest average annual rainfall in England. The Environment Agency estimates that more than 28,900 North West properties are at significant risk of flooding from rivers or the sea, 6 per cent of the total in England.

\section{Population}

In 2009, the estimated population of the North West was 6.9 million, representing 11.2 per cent of the population of the UK. This was the third largest among the regions of England and countries of the UK, with only London and South East having higher populations.

Figure 3 shows the mid-2009 population of the counties and unitary authorities (including metropolitan districts) as defined from April 2009. The former metropolitan counties of Greater Manchester and Merseyside have populations of 2.6 and 1.4 million respectively.

Manchester city $(483,800)$ had the eighth largest population of any local authority in the UK and Liverpool $(442,300)$ was eleventh largest, both similar in size to Cumbria. The largest nonmetropolitan districts - Lancaster $(140,000)$ and Preston $(135,000)$, both in Lancashire - are similar in population to the older unitary authorities. Eden in Cumbria $(51,800)$, Ribble Valley $(57,700)$ and Rossendale $(67,100)$ - both in Lancashire - were the least populous local authorities in the region. 
The North West had the second highest regional population density in the UK with 489 people per sq $\mathrm{km}$ in 2009, compared with the UK and England densities of 255 and 398, respectively. London was the only other region in the UK with a higher population density, at 4,932 people per sq $\mathrm{km}$ which is over 10 times the density of the North West. Within the North West, the population density varied substantially, ranging from 24 people per sq km in Eden to 4,184 per sq km in Manchester. The former has the lowest population density in England, but there are 26 English unitary authorities that are more densely populated than Manchester.

\section{Figure $3 \quad$ Mid-year population: by county and unitary authority}

North West, 2009

Thousands

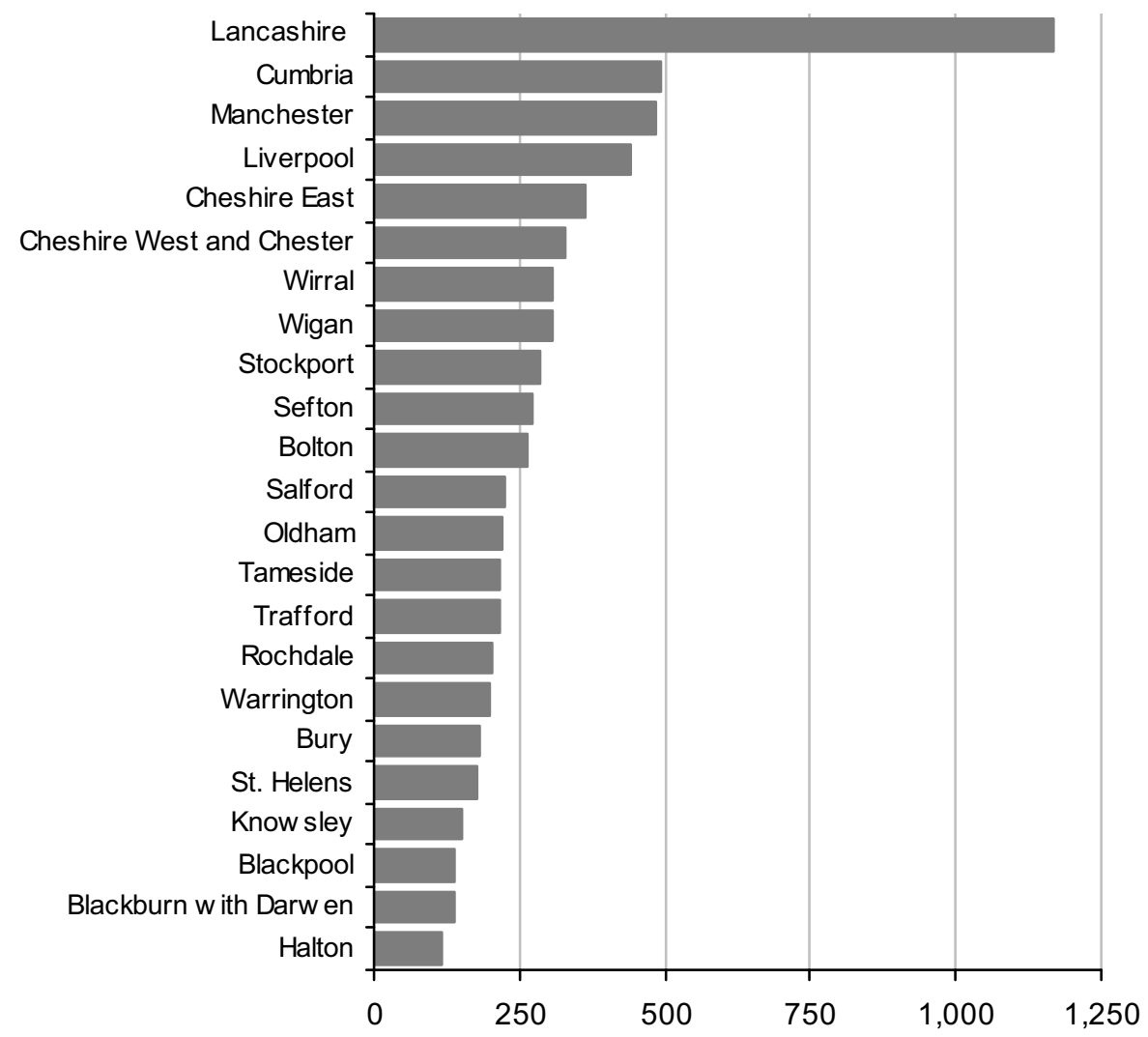

Source: Office for National Statistics

In the five years to mid-2009, the region's population grew by 1.2 per cent, the smallest growth rate of the 12 UK countries and regions. Among the 39 North West districts and unitary authorities, percentage growth was highest in Manchester (10.3 per cent), Salford (3.2 per cent), Warrington (3.0 per cent), and South Ribble in Lancashire (2.5 per cent). There were reductions in 11 local authorities, the largest being around 2 per cent in Blackpool, Burnley, and Sefton (see Map 4).

Between mid-2008 and mid-2009 the North West population grew by 23,800 or 0.3 per cent. This was lower than the UK average ( 0.6 per cent), with Wales the only UK country or English region which had a smaller percentage increase than the North West. 


\section{Map 4 Percentage change in population: by local or unitary authority ${ }^{1}$,} 2004-2009

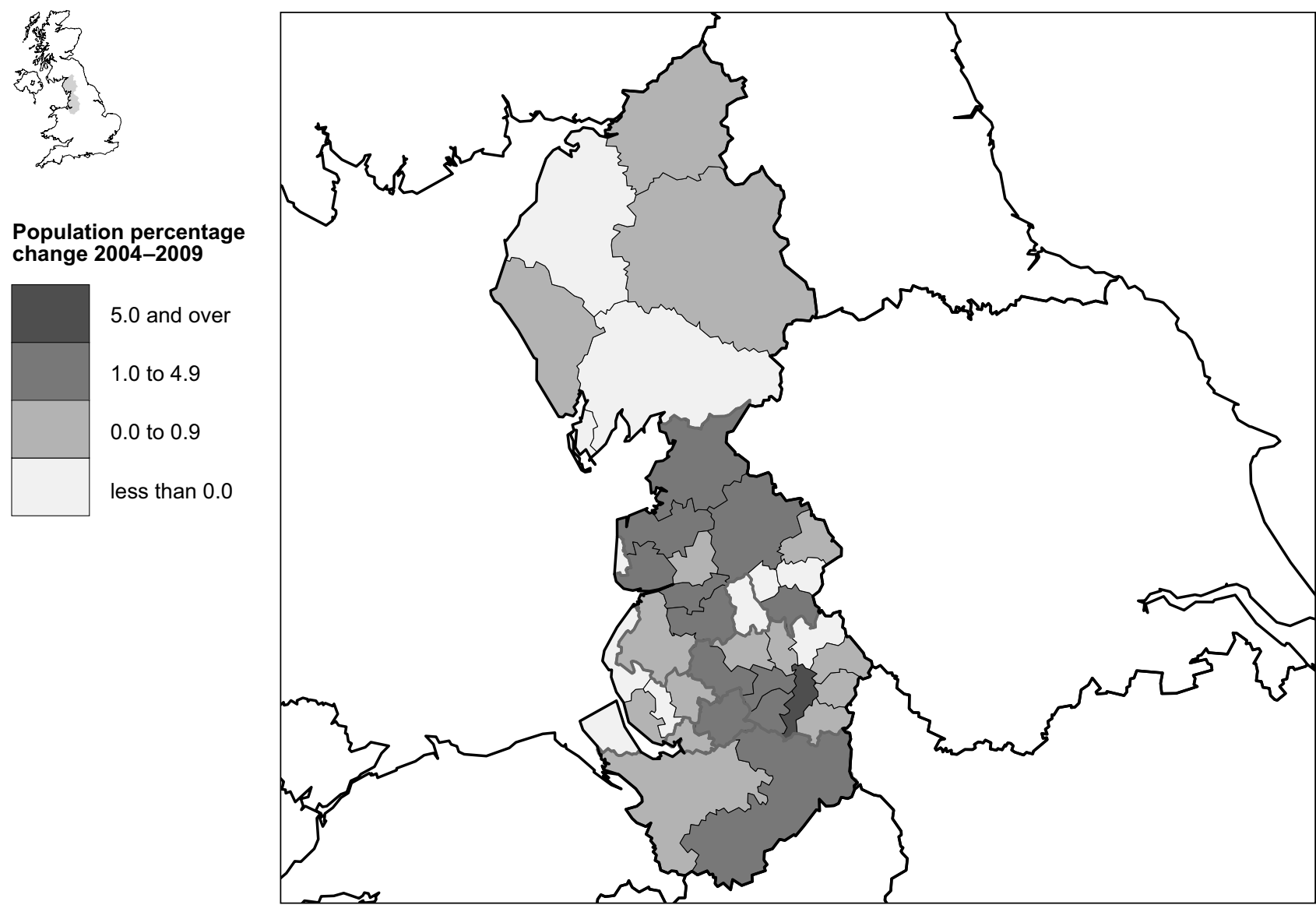

1 For key to local authorities see Map 2

(c) Crown copyright and database right 2011. Ordnance Survey Licence 100019153

Source: Office for National Statistics

Net migration and other changes, from other parts of the UK or abroad, accounted for 6,000 (25 per cent) of the North West increase between mid-2008 and mid-2009. This means that 75 per cent of the population increase was due to natural change (that is, the excess of births over deaths). Within the region, the largest increases due to both natural change and net migration and other changes were seen in Manchester (3,900 and 6,800 respectively) (see Figure 5). The largest decrease due to natural change was seen in Sefton (deaths exceeding births by 500 ) and the largest decrease due to net migration and other changes, was seen in Preston (a decrease of $1,400)$.

There were nearly 88,000 live births in the North West in 2009. The Total Fertility Rate (TFR) - the number of children that women would have, on average, if they experienced the current patterns of fertility throughout their childbearing life - was 2.00. This was above the English average of 1.96 and the second highest of the English regions, behind West Midlands. Within the region, the TFR varied from 1.59 in Lancaster to 2.55 in Blackburn with Darwen. 


\section{Figure 5 Components of population change}

Local authorities in the North West with the 6 highest and 6 lowest total population percentage change, 2009

Percentage of population

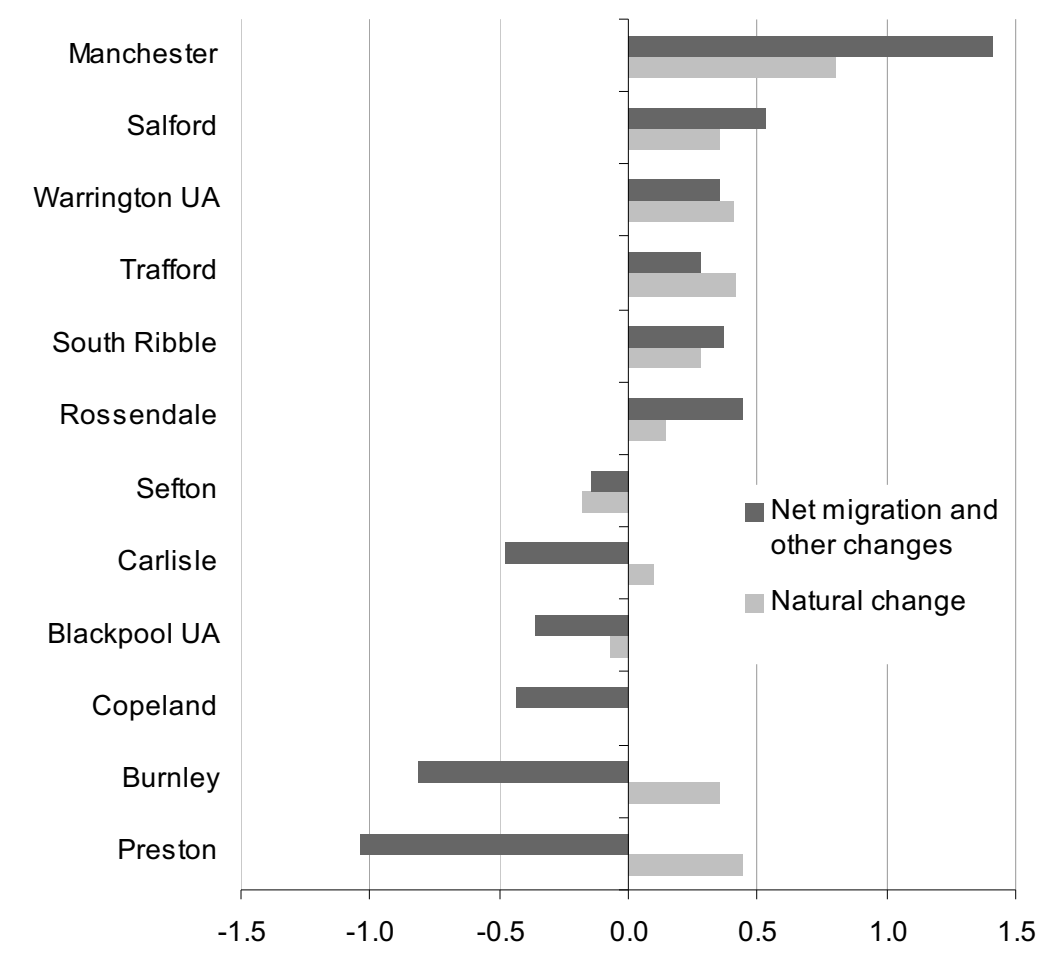

Source: Office for National Statistics

The population of the North West has a similar age structure to the UK, as the mid-year 2009 population pyramid in Figure 6 indicates. The differences are most noticeable in the 25 to 39 -yearold groups where the national proportions are over one percentage point higher than those of the North West and among 15 to 24 -year-old where the reverse is true.

The 2008-based population projections suggest that the population of the North West will reach 7.5 million by 2033 (around 9 per cent more than in 2008) if recently observed trends in births, deaths and migration were to continue. This is the lowest projected increase of all the English regions, and is half the rate of growth projected for England as a whole (18 per cent over the same period). The projections show the number of children increasing by 50,000 or 4 per cent, and the number of people of pension age increasing by 631,000 (using the pension age of 60 for women and 65 for men that applied up to 2010) - a rise of 47 per cent. Conversely, the working-age population is projected to fall by 84,000 , or 2 per cent. This is one of two regions projected to experience a decrease in the number of working-age people; the other is the North East.

According to mid-2007 experimental estimates by ethnicity, people from non-White groups made up 8 per cent of the region's population. This was the third lowest of all the English regions: only the North East and the South West had a lower proportion of non-White population. Asian or Asian British people were the largest non-White ethnic group in the region, comprising over 4 per cent of the total population. This is a higher proportion than the 3 per cent of North West people describing themselves as 'White - Other' (that is, White, non-British and non-Irish). More than 20 per cent of 


\section{Figure 6}

Mid-year population estimates: by 5-year age band and sex

North West, 2009

Percentages

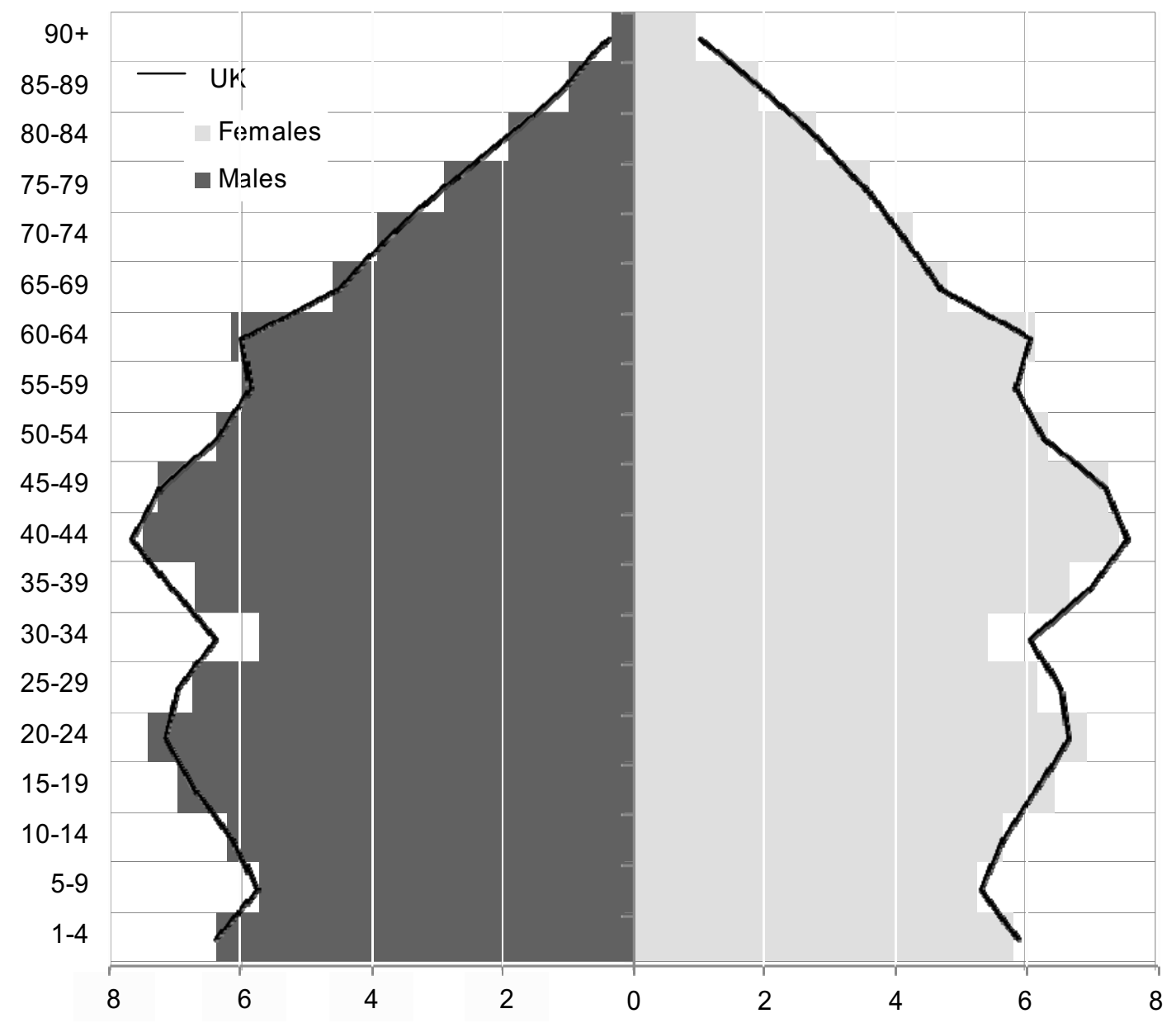

Source: Office for National Statistics

the non-White population of the North West lived in Manchester metropolitan district, despite the fact that it had only 8 per cent of the region's total population.

According to the Annual Population Survey, in the year to December 2009, around 93 per cent of the population of the North West were born in the UK, higher than the UK average of 89 per cent. The North West had the third highest proportion of people born in the UK among the English regions behind the North East and the South West. The variation in the proportion of UK born residents at county and unitary authority level in the region is considerable, from 76 per cent in Manchester to 98 per cent in Knowsley. 


\section{Households and housing}

There were an estimated 2.9 million households in the North West in 2008, approximately 14 per cent of the total in England. The average household size was 2.3 people, the third lowest (behind North East and South West) among the nine English regions.

Approximately 50 per cent of North West households contained couples, the second lowest (behind London) in all nine English regions. Approximately 35 per cent of households contained one person, which is the second highest proportion, with London being the highest of all of the nine English regions. However, both of these proportions were close to the England equivalent (53 per cent and 34 per cent respectively).

The total number of households in the North West is projected to reach almost 3.5 million in 2033, if recently observed trends were to continue, according to projections based on mid-2008 data. This is equivalent to an 18 per cent increase over the 25 years, the smallest change among English regions in percentage terms. The increase reflects the projected 9 per cent growth in the region's population during this period combined with the projected fall in the average North West household size to 2.1

\section{Figure $7 \quad$ Household numbers and projections}

North West

Thousands

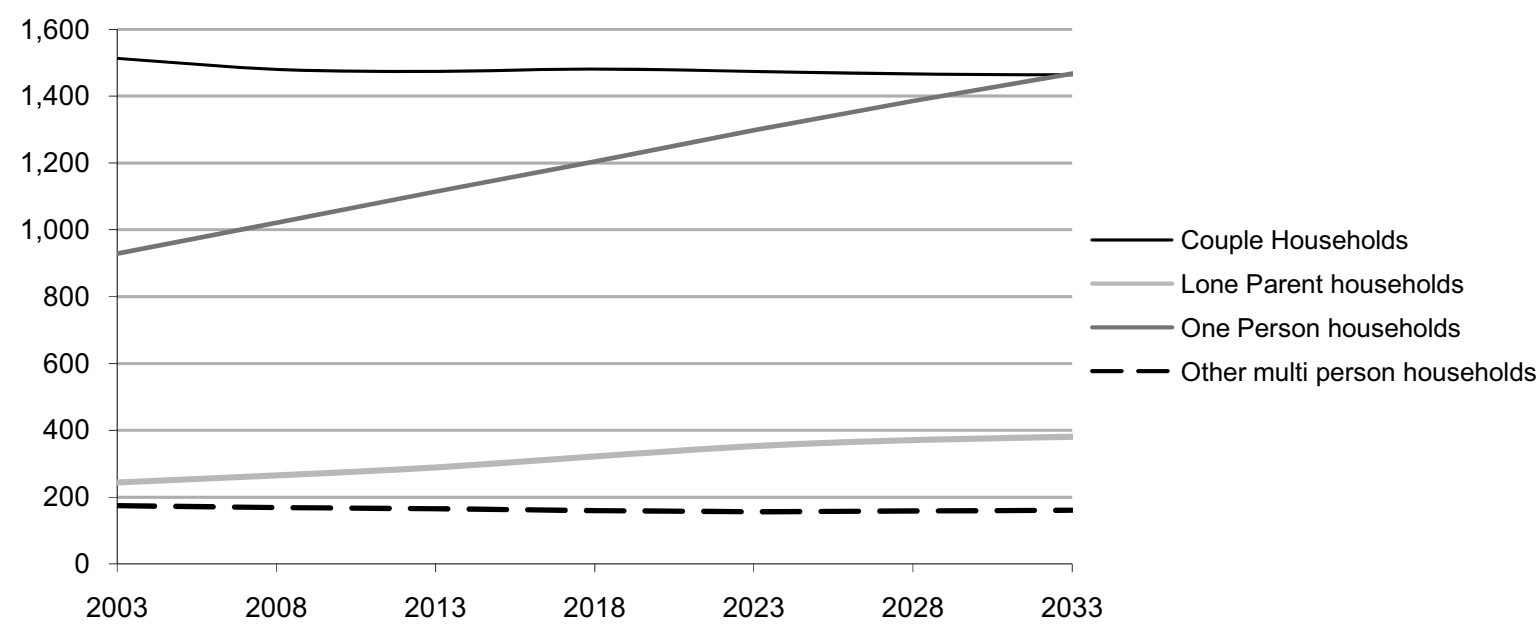

Source: Communities and Local Government

Figure 7 illustrates actual and projected changes in the number of households in the region between 2003 and 2033 broken down by type. It highlights the fact that the number of one-person households is projected to equal the number of couple households by 2033.

In 2009 there were 3.1 million dwellings in the North West, which represents 14 per cent of England's housing stock. The stock of dwellings grew by 5.9 per cent between 1999 and 2009; this was the second smallest rise of any English region, no surprise given the relatively slow population growth in the region. 
In 2007, 71 per cent of dwelling stock was owner-occupied; only slightly higher than the England proportion (70 per cent), while 12 per cent was rented from a registered social landlord, the highest percentage among the English regions. The remaining 17 per cent were rented from local authorities or privately rented or with job or business; the smallest proportion in England.

In 2009/10, 9,900 dwellings were completed in the North West; a decrease of 28 per cent compared with 2008/09. Yorkshire and The Humber was the only other English region to have a slightly larger percentage decrease (29 per cent). The number of completions for the private sector in the region $(8,900)$ was at its lowest level, almost a third lower than in $2008 / 09$. However, completions for registered social landlords (900) were the highest since 2006/07.

The median house price in the North West in 2009 was $£ 130,000$, compared with $£ 170,000$ for England. This was unchanged from 2008. More recent data indicate that in the first quarter of 2010 , the median house price in the North West was $£ 123,000,3$ per cent below that of the same period a year earlier. In 2009, only three of the 39 districts and unitary authorities in the region had a median house price above the England median. None were within the highest quarter of English local authorities for median house prices.

One measure of housing affordability is to compare lower quartile house prices against lower quartile earnings of workers in the area (Box 1). The higher the ratio of house prices to earnings, the less affordable are properties in the area. Using this measure, houses were more affordable in the North West than in any other English region, with the exception of the North East. In 2009 the ratio of lower quartile house prices to earnings in the North West was 5.0, compared with the England average of 6.3 .

\section{Box 1 Measuring housing affordability}

An important indicator of housing affordability is the ratio of lower quartile house prices to lower quartile incomes. The lower quartile value for a particular area is determined by ranking all prices or incomes in ascending order and identifying the value below which 25 per cent fall. The statistics used for lower quartile income are workplace based annual full-time individual earnings from the Annual Survey of Hours and Earnings (ASHE). The ASHE is based on a 1 per cent sample of employee jobs in April of a given year. It does not cover the self-employed nor does it cover employees not paid during the reference period.

Lower quartile house prices are based on Land Registry data for the first two quarters of a given year. Each ratio is calculated by dividing the house price by income. Data for local authorities in England and Wales can be accessed on the Communities \& Local Government (CLG) website: www.communities.gov.uk/housing/housingresearch/housingstatistics/housingstatisticsby/ 
As Map 8 illustrates, the North West has a relatively large share of local authority districts with low house prices relative to earnings. In 23 of the North West's 39 districts and unitary authorities the lower quartile house price ratio was among the lowest 20 per cent of ratios found in English local authorities. Six of these were among the 10 authorities in England with the lowest ratios.

Conversely, two of the North West's 39 districts and unitary authorities had a lower quartile house price ratio that was among the highest 20 per cent of ratios found in English local authorities; Eden (9.7) and South Lakeland (8.8).

\section{Map 8 Ratio ${ }^{1}$ of lower quartile house prices to lower quartile earnings: by local or unitary authority², 2009}

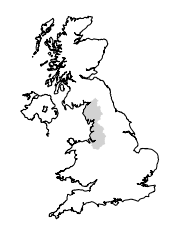

\section{Lower quartile house} price ratio $^{3}$

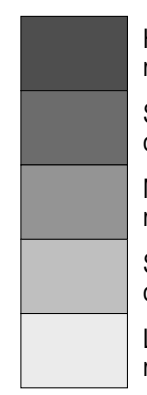

Highest $20 \%$ of
ratios in England Second highest $20 \%$ of ratios in England

Middle $20 \%$ of ratios in England Second lowest 20\% of ratios in England Lowest $20 \%$ of ratios in England

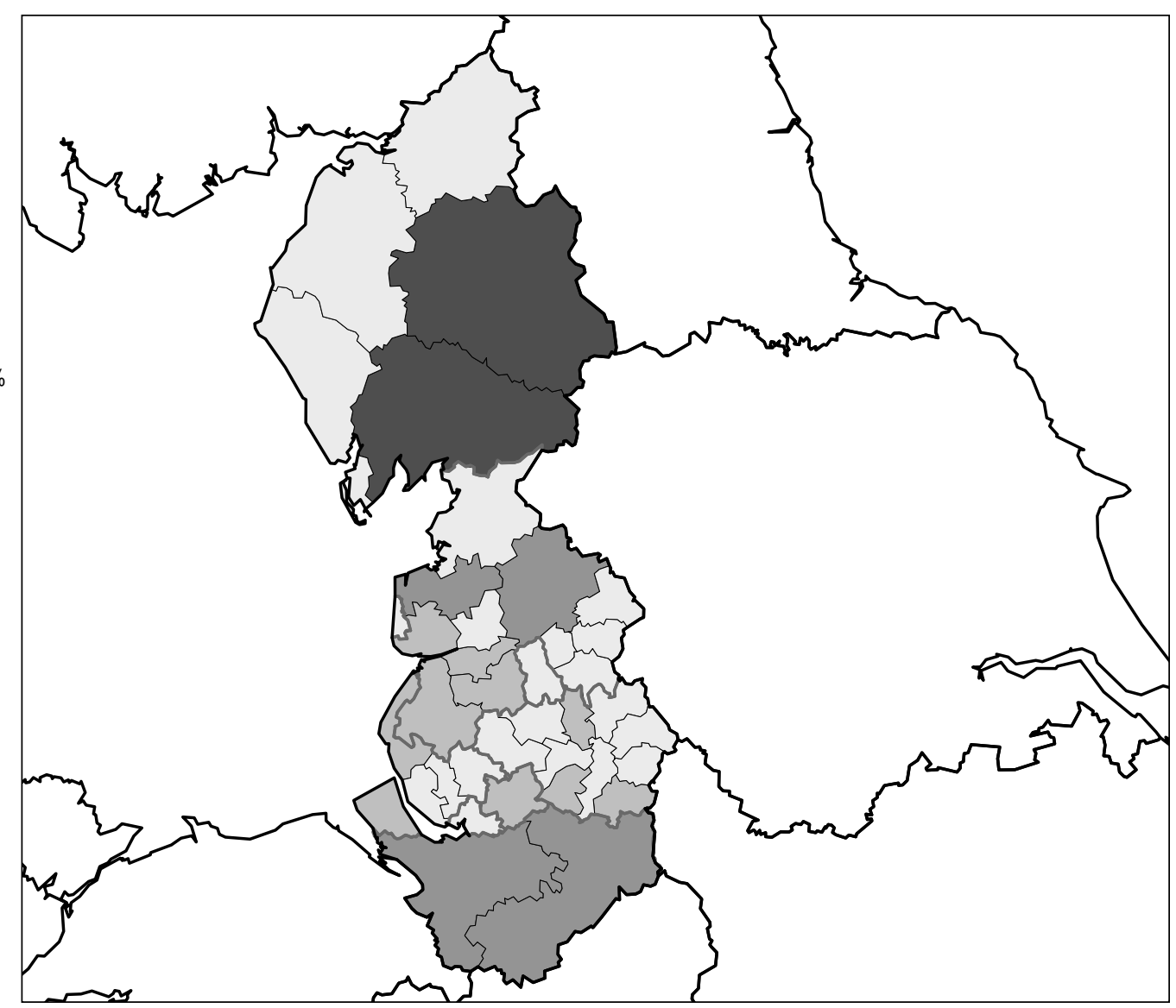

(c) Crown copyright and database right 2011. Ordnance Survey Licence 100019153.

1 A higher ratio means less affordable house prices.

2 For key to local authorities see Map 2.

3 There were no local authorities in the North West in 2009 with a lower quartile house price ratio in the second highest 20 per cent of these ratios across England.

Source: Annual Survey of Hours and Earnings (Office for National Statistics); Communities and Local Government; HM Land Registry 


\section{Education and Skills}

The proportion of Key Stage 4 pupils in maintained schools in the North West who achieved five or more GCSEs at grades $A^{*}$ to $C$ or equivalent in 2009/10 (provisional results) was second highest of all the English regions, 1.6 percentage points higher than the England average of 75.7 per cent. Within the North West, the proportion of pupils achieving 5 or more GCSEs at grades $A^{*}$ to $C$ ranged from 86.6 per cent in Trafford to 67.5 per cent in Knowsley.

The proportions of 16 and 17-year-olds participating in post-compulsory full-time education and government-supported training in the North West (87 per cent and 76 per cent respectively in 2008/09) were similar to the England averages of 88 per cent and 76 per cent.

North West universities attracted almost 250,000 full- and part-time students in 2008/09, 10 per cent of all students at UK universities. International students constituted approximately 12 per cent of the North West student population. The majority of international students (72 per cent) were from non EU countries.

In 2009 the region had one of the highest proportions of the working-age population (aged 16 to 64 ) that had no qualifications, 14 per cent compared with the England average of 12 per cent (Figure 9). The proportion of the North West's working-age population with qualifications at National Qualifications Framework (NQF) Level 4 was 27 per cent, below the England average of 30 per cent.

\section{Figure 9 Proportion of working age population with no qualifications: by region}

England, 2009

Percentages

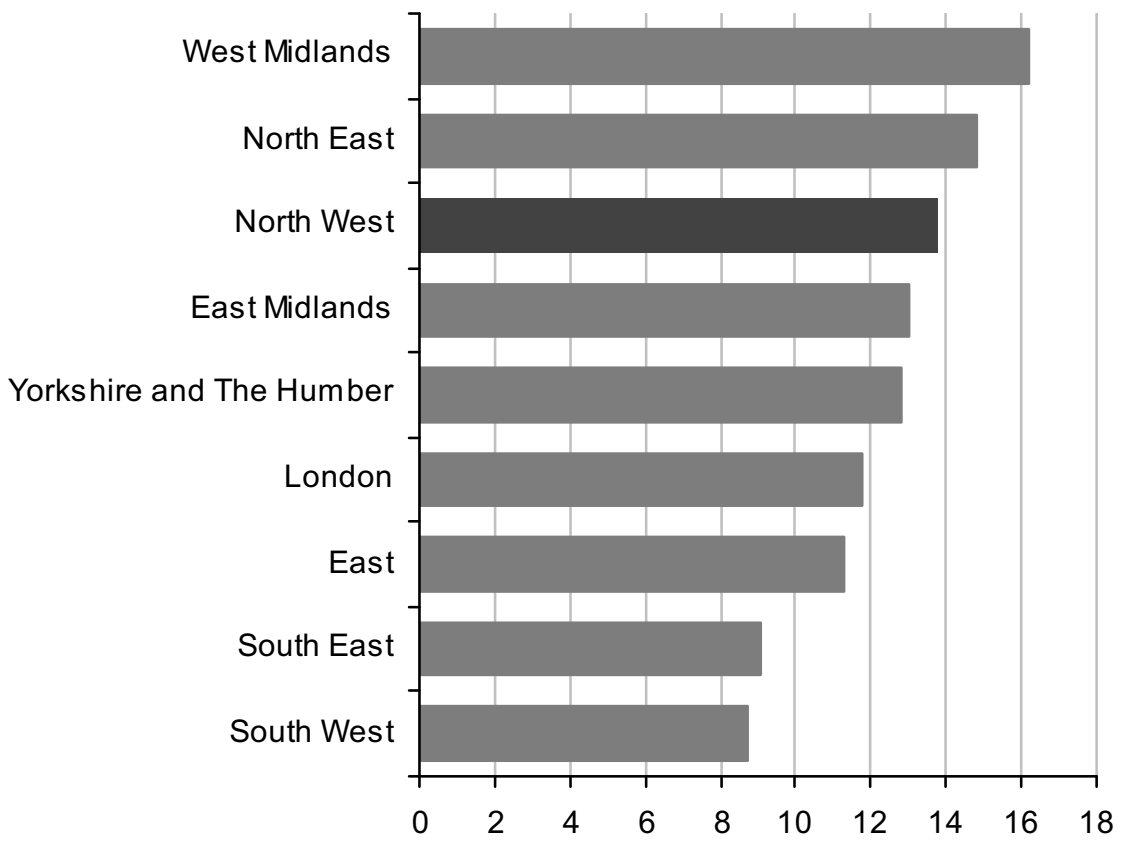

Source: Department for Business Innovation and Skills 
The older age groups in the resident population are more likely to have no qualifications than those in younger age groups. In the North West in 2009 over 15 per cent of the economically active population aged 50 to 64 had no qualifications (slightly higher than the England average at 13 per cent) compared with 7 per cent of those aged 16 to 24 and 6 per cent of those aged 25 to 49 .

\section{Labour market}

The North West has rates of employment that are among the lowest in the UK. In the third quarter of 2010 , the employment rate for residents of working-age was 69.4 per cent compared with 70.8 per cent for the UK average. This was 0.5 percentage points higher than in the same quarter of 2009. Figure 10 illustrates that the long-term trend has been below the UK average by a margin that ranged from 3 percentage points in Q3 1998 to 1 percentage point in Q3 2010.

\section{Figure 10 Employment rate}

North West, 1992 Q3 to 2010 Q3

Percentages

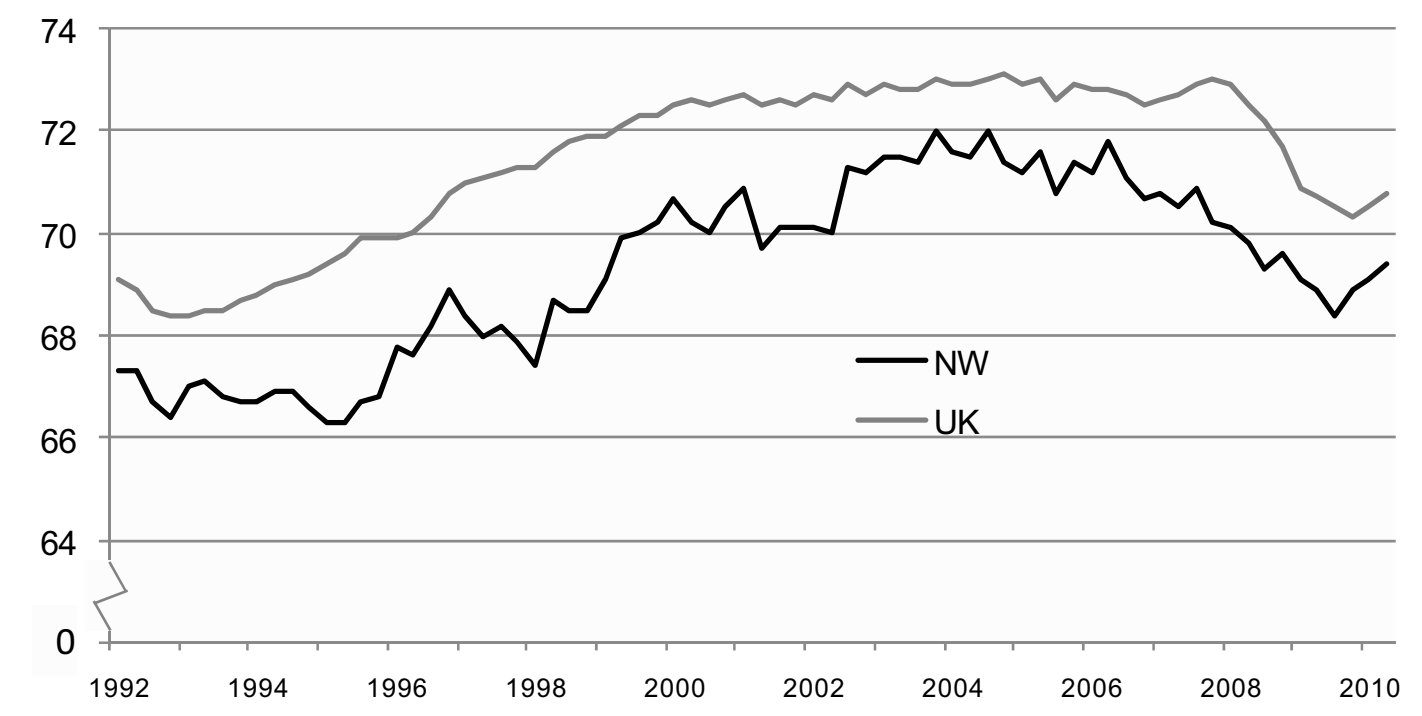

Source: Labour Force Survey, Office for National Statistics

At a local level, working-age employment rates within the region ranged from 79 per cent in Eden to 60 per cent in Liverpool for the year ending December 2009. The regional average during this period was 68 per cent.

In the third quarter of 2010, the North West unemployment rate was 8.0 per cent of the economically active population, slightly above the national rate of 7.7 per cent. The North West rate was 0.6 percentage points lower than a year earlier, the UK rate had fallen by 0.1 percentage points in the same period.

At a local authority level, unemployment rates are modelled to provide greater precision than survey estimates. The latest available at the time of writing were for the year to December 2009, 
with equivalent regional and UK rates of 8.5 and 7.6 per cent respectively. Within the North West, the highest unemployment rates were in Liverpool (12.3 per cent), Manchester (12.2 per cent) and Halton (11.0 per cent), and the lowest were in Eden (2.8 per cent) and South Lakeland (3.1 per cent).

The Jobseeker's Allowance claimant count rate, a timelier but more narrowly defined indicator of unemployment, also tends to be slightly higher in the North West than across the UK. In December 2010, 4.0 per cent of the region's working-age population were claiming Jobseeker's Allowance, compared with 3.6 per cent nationally. At a local level, this rate was highest in Liverpool (6.4 per cent), Knowsley (5.8 per cent) and Blackpool 5.7. It was lowest in Eden, South Lakeland and Ribble Valley (all at 1.2 per cent).

\section{Figure 11 Claimant count: by sex}

North West,

Thousands

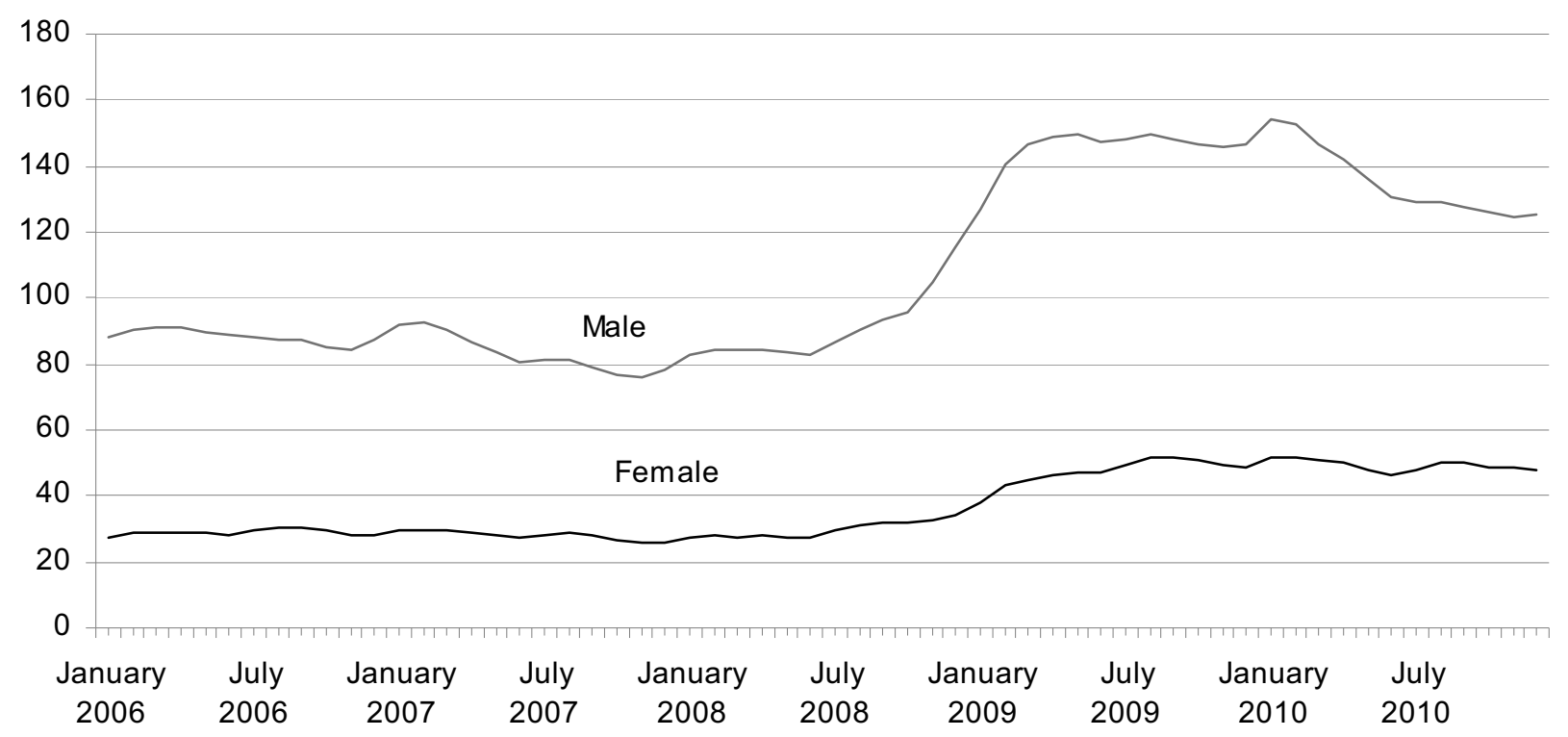

Source: Office for National Statistics

The claimant count for males increased sharply from August 2008, with month-on-month increases reaching over 10 per cent in December 2008 to February 2009, before starting to decline in February 2010 (see Figure 11). The claimant count for females showed lower increases until January and February 2009 when month-on-month increases exceeded 10 per cent, before the count levelled off again. 
In the year ending Q2 2010, 25 per cent of working-age people in the region were economically inactive, compared with 23 per cent for the UK average. Only the North East, London, Northern Ireland and Wales had higher rates. About 18 per cent of North West working-age men and 31 per cent of women were economically inactive; both 1 percentage point above the UK equivalent.

The three main reasons for being economically inactive in the year ending December 2009 within the North West were long-term sickness (30 per cent), studying, and looking after family or home (both 22 per cent). The North West had the fourth highest proportion of working-age people who were economically inactive because of long-term sickness among the UK counties and English regions (see Figure 12).

\section{Figure 12 Reasons for economic inactivity ${ }^{1}$}

North West, 2009

Percentages

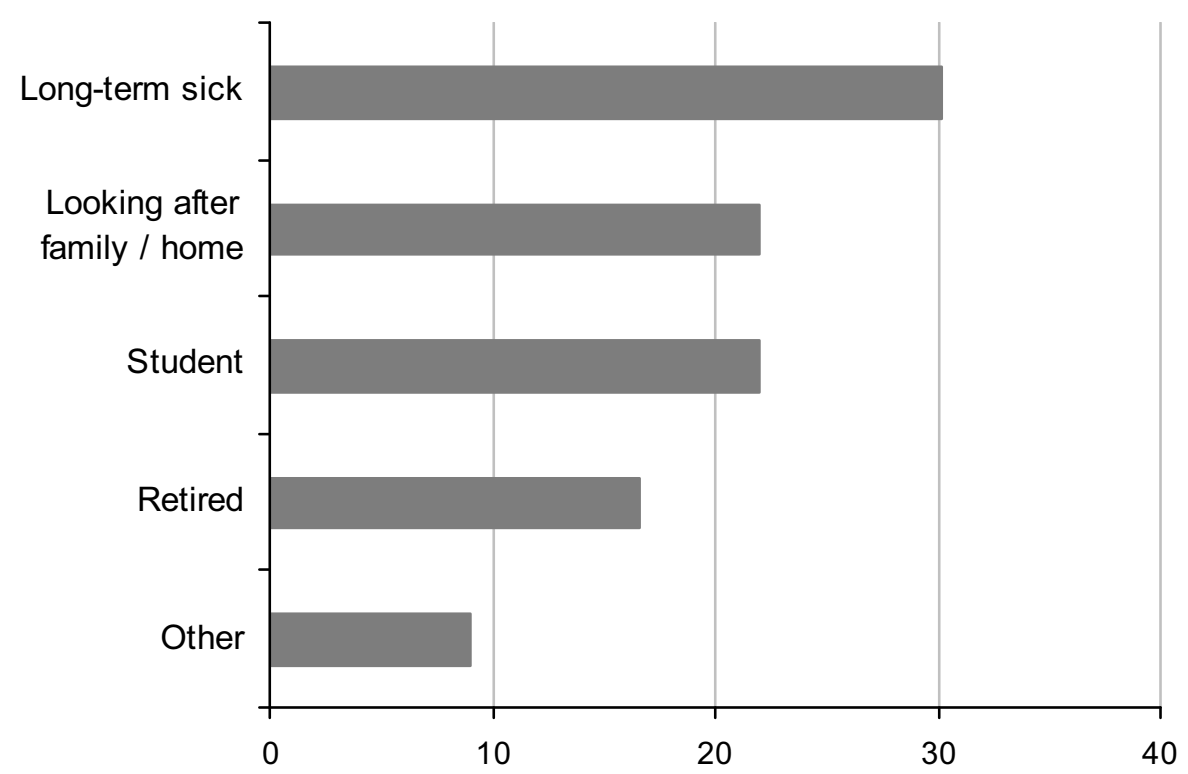

Source: Annual Population Survey, Office for National Statistics

1 As a percentage of all working-age economically inactive people. 
Median gross weekly earnings, including overtime, of full-time employees resident in the North West in April 2009 were $£ 460$, with $£ 498$ for men and $£ 408$ for women. This is lower than the UK median earnings of $£ 489$, and similar to earnings in Scotland, Yorkshire and The Humber, and the Midlands. As Figure 13 illustrates, within the North West, the highest unitary authority/district median gross weekly earnings were in Copeland (£625), Fylde (£538) and Trafford (£537), and the lowest were in Eden (£368) and Blackpool (£373).

\section{Figure 13 Median gross weekly earnings for full-time employees: by county and unitary authority of residence}

North West, April 2009

$£$ per week difference from UK average

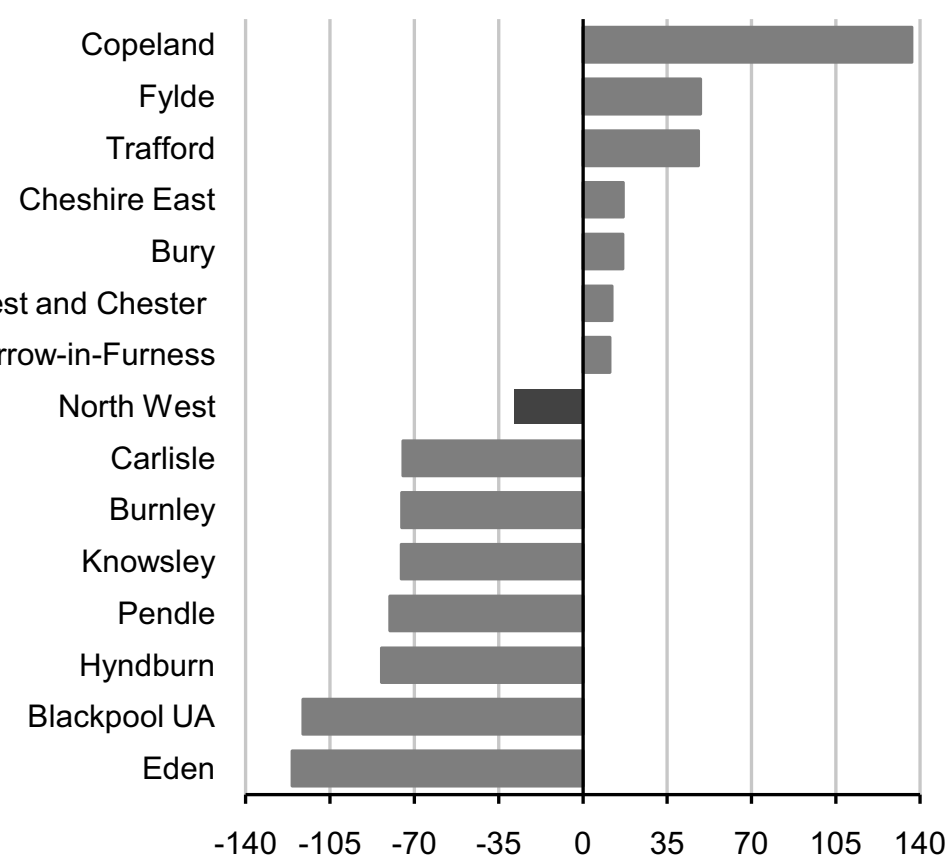

Note: UK average $=£ 488.70$ per week

Source: Annual Survey of Hours and Earnings, Office for National Statistics 


\section{Economy and industry}

In 2009 the North West generated $£ 119$ billion of gross value added (GVA), almost 10 per cent of the UK total. The decrease of 1.6 per cent in total GVA between 2008 and 2009 was one of the smallest decreases among the English regions, similar to the North East and London, compared with the average UK decrease of 2.1 per cent. In 2008, almost two-fifths (39 per cent) of the region's total GVA was produced in Greater Manchester.

Productivity as measured by GVA per hour worked, which takes into account factors such as commuting patterns and hours of work, was 88 per cent of the UK rate in 2008, the third lowest of the 12 UK countries and regions. GVA per filled job in the North West in 2008 was 87 per cent of the UK rate, the fourth lowest (see Figure 14).

\section{Figure 14 Gross value added per hour worked: by country and region}

United Kingdom, 2009

Difference from UK $(U K=100)$

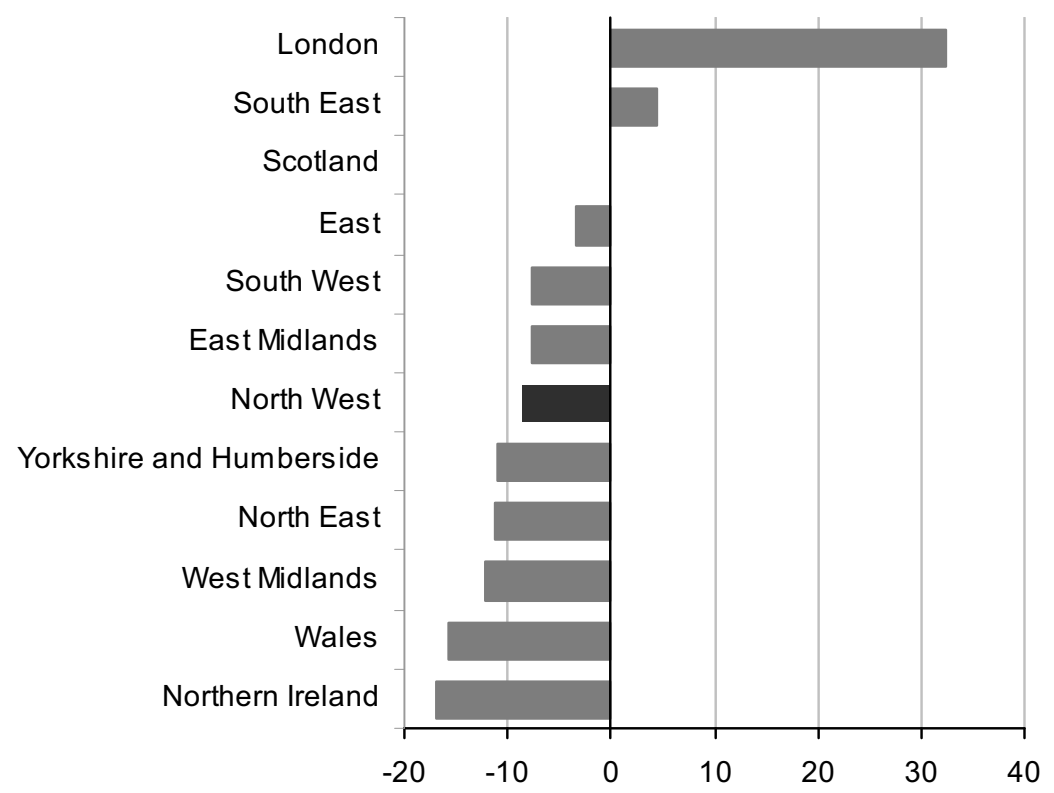

Source: Office for National Statistics 


\section{Box 2 Measuring Regional Economic Performance}

When measuring the economic performance of regions or sub-regions, the following should be considered:

Gross Value Added (GVA) is a good measure of the economic output of a region.

GVA per head, which divides output of those working in a region by everybody living in the region, should not be used as an indicator of either regional productivity or income of residents.

GVA per hour worked and GVA per filled job are the preferred measures of productivity of an area.

Gross Disposable Household Income (GDHI) per head is a good indicator of the welfare of residents living in a region. GDHI is the amount of money households have available for spending or saving.

Productivity, Income and Labour Market indicators should be used together to provide a more complete picture of regional and sub-regional economic performance.

For further information, see the National Statistician's article 'Measuring regional economic performance', which can be found at www.statistics.gov.uk/cci/article.asp?ID=2103

and the Regional Economic Indicators articles published in Economic and Labour Market Review, for example: www.statistics.gov.uk/cci/article.asp?|D=2642

The industry groups that most contributed to the region's total GVA in 2008 were broadly similar to those for the whole UK, although a higher proportion was produced by manufacturing. Three industry groups were responsible for over half: real estate, renting and business activities (22 per cent of North West GVA, 24 per cent of the UK's), manufacturing (16 per cent of North West GVA, 12 per cent of the UK's) and the wholesale and retail trade (12 per cent in both cases).

The manufacturing industry makes a larger contribution to UK GVA for this industry sector than in any other English region or country of the UK: 13 per cent of the UK's GVA from manufacturing was generated in the North West in 2008. Within manufacturing industry, 39 per cent of UK GVA from 'coke, refined petroleum and nuclear fuels' was accounted for by the North West; 21 per cent of 'chemicals, chemical products and man-made fibre'; and 16 per cent of transport equipment.

In terms of employment, service industries provide the majority of jobs in the North West, equivalent to the UK proportion. Short-term Employment Survey data show that in June 2010, 82 per cent of employee jobs were in service industries (the same as the UK) while just over 10 per cent were in manufacturing ( 8 per cent for the UK). The three largest service industry groups were a similar size in the North West to nationally. However, of these, the region had higher than average proportions of employee jobs in wholesale; retail trade and repairs; manufacturing; transport and storage; and in health and social work. It had a below average percentage of employee jobs in professional, scientific and technical activities; financial and insurance activities; and information and communication. 
Among the region's 39 districts and unitary authorities, Manchester (94 per cent) and Liverpool (91 per cent) had the highest proportions of employee jobs in service industries, according to the 2008 Annual Business Inquiry. Liverpool and Manchester combined accounted for 20 per cent of all North West employee jobs in the services industry. Copeland on the Cumbria coast based on the small port of Whitehaven (33 per cent) and Fylde in Lancashire, which is on the Ribble estuary based round Lytham St Annes, (31 per cent) had the highest proportions of employees in manufacturing (see Map 15). However, together they accounted for only 7 per cent of the region's manufacturing employee jobs.

\section{Map 15 Percentage of employees in manufacturing: by local or unitary authority ${ }^{1}, 2009$}

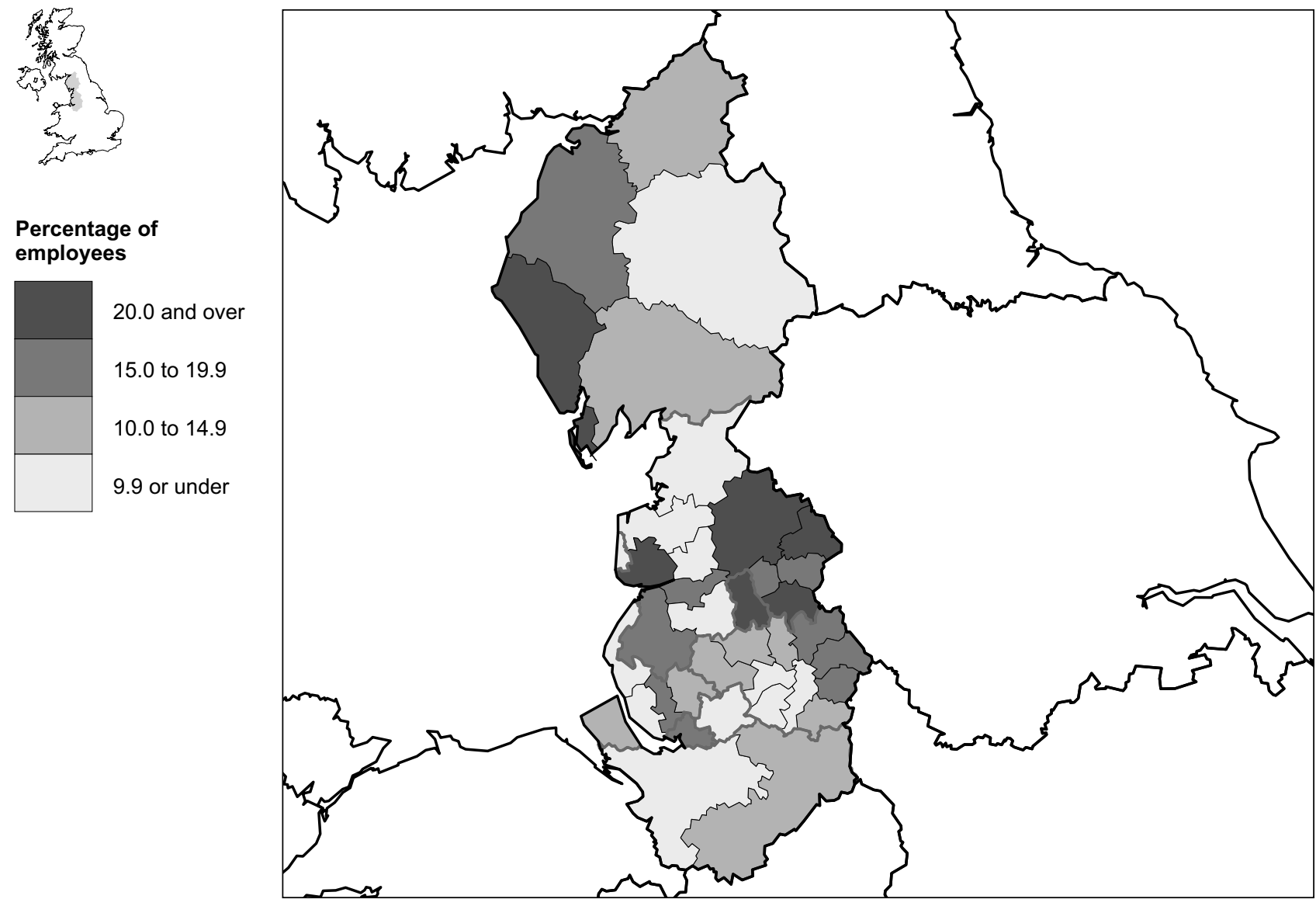

๔ Crown copyright and database right 2011. Ordnance Survey Licence 100019153.

1 For key to local authorities see Map 2.

Source: Office for National Statistics 
In 2008 UK residents visiting the North West spent 37 million nights and £2.3 billion in the region, representing 10 per cent and 11 per cent of the UK totals respectively. Overseas visitors spent 17 million nights and $£ 850$ million, the fourth highest among UK countries and regions.

In 2008 almost $£ 2.9$ billion was spent on research and development (R\&D) in the North West, the fourth highest figure among the UK countries and regions, after London, East and South East. Some 78 per cent of this was spent by businesses, a higher proportion than nationally (63 per cent) and the second highest regional proportion. Figure 16 shows that as a percentage of GVA, the North West's total R\&D expenditure was the third highest.

In the North West, gross disposable household income (GDHI) per head was $£ 13,300$ in 2008; this was below the UK equivalent ( $£ 14,900$ per head). Within the region, GDHI per head ranged from 27 per cent below the UK figure in Blackburn with Darwen to 9 per cent above in Cheshire County Council NUTS 3 (Nomenclature of Units for Territorial Statistics, level 3) area.

\section{Figure 16 Expenditure on research and development as a proportion of gross value added: by country and region}

United Kingdom, 2008

Percentages

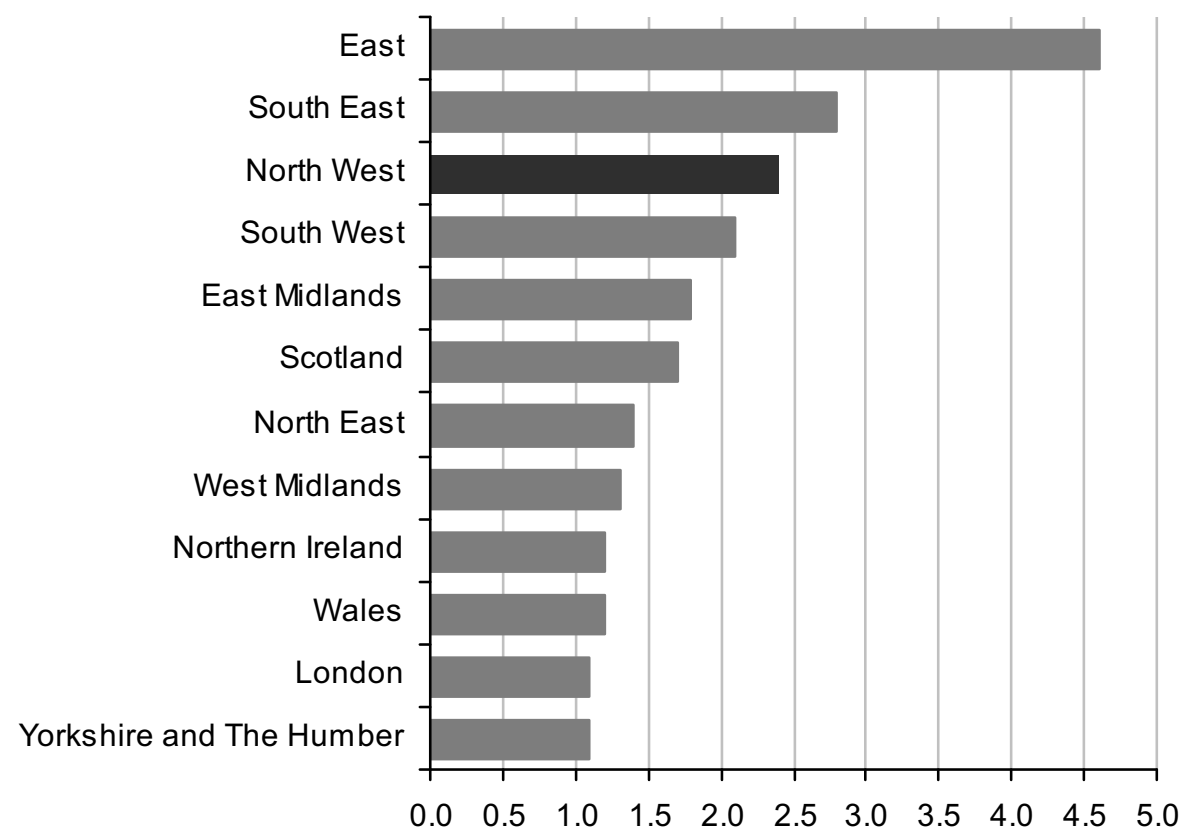

Source: Office for National Statistics 


\section{Disadvantage}

According to the 2007 Index of Multiple Deprivation (IMD 2007), 32 per cent of North West Lower Layer Super Output Areas (LSOAs) were within the most deprived quintile (20 per cent - see Box 3 ) in England. This was the second highest proportion among the nine English regions, behind the North East. Greater Manchester and Merseyside together contained nearly three-quarters of the region's population living in the most deprived quintile. As Figure 17 indicates, the most deprived districts were Liverpool, Manchester and Knowsley all with about two-thirds of LSOAs in the most deprived quintile. However, Sefton, Trafford, Stockport and Bury all had less than 20 per cent of LSOAs in the most deprived quintile (and Sefton none at all).

Among the non-metropolitan unitary authorities, Blackburn with Darwen and Halton had the largest proportions of LSOAs (around half) in the most deprived quintile.

By far the highest proportion of LSOAs in the least deprived quintile was in the new unitary authority of Cheshire East (46 per cent). In terms of the former districts the highest concentrations were in Congleton with 57 per cent and Macclesfield with 54 per cent. Liverpool, Manchester, Knowsley and Blackpool had no LSOAs in the least deprived quintile.

\section{Box $3 \quad$ Index of Multiple Deprivation 2007}

The Index of Multiple Deprivation (IMD) provides a summary measure of relative deprivation at Lower Layer Super Output Area (LSOA) level in England. The IMD aims to provide a nationally consistent measure of how deprived an area is by identifying the degree to which people are disadvantaged by factors such as low income, unemployment, lack of education, poor health, and crime. Particular points to note:

- Not all deprived people live in deprived areas and conversely, not everyone living in a deprived area is deprived; the indicators identify areas with characteristics associated with deprivation - not deprived people

- The indices should not be used as a measure of affluence: a lack of income deprivation does not necessarily equate to affluence

- The indices provide a relative measure of deprivation and therefore cannot be used to determine how much more deprived one LSOA is than another

This article uses the rankings of all LSOAs in England, which have been divided into five equal sized groups, or quintiles. In England 20 per cent of LSOAs are in the most deprived quintile and 20 per cent in the least deprived quintile and so on. If an area (region or local authority) had the average distribution of deprivation they would have 20 per cent of LSOAs in each quintile.

For more information on the IMD see the Neighbourhood Statistics website:

www.neighbourhood.statistics.gov.uk 


\section{Figure 17 Distribution of LSOA ${ }^{1}$ rankings on the 2007 Index of Multiple Deprivation: by county and unitary authority}

North West, 2007

Percentages

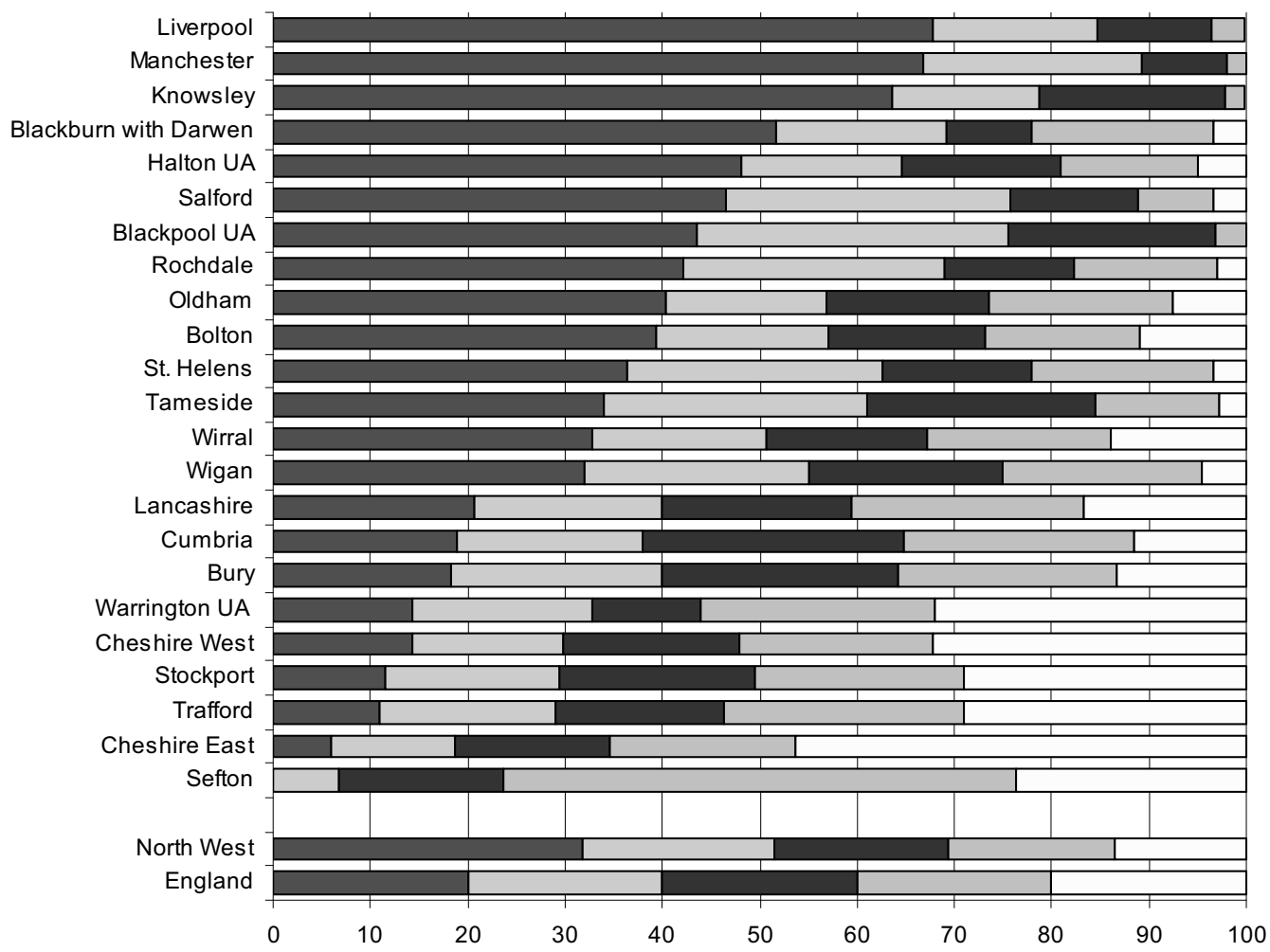

口 Most deprived $20 \%$

口 20\%-40\%

口 $40 \%-60 \%$

$\square 60 \%-80 \%$

$\square$ Least Deprived 20\%

1 Lower Layer Super Output Areas.

Source: Communities and Local Government

In the second quarter of 2010 there were 483,000 working-age households in the North West where no adult worked. This was 21 per cent of the total number of households in the North West and 2 percentage points higher than a year earlier. About 17 per cent of children in the region lived in a workless household, almost 3 percentage points lower than in 2009. Both were the second highest regional proportions, behind London. The latest data for local areas (see Map 18) indicates that in 2009, within the North West, the proportion of workless households ranged from 32 per cent in Liverpool - highest in the UK - to around 11 per cent in Macclesfield, South Lakeland and Ribble Valley (Lancashire). 


\section{Map 18 Percentage of workless households ${ }^{1}$ : by local or unitary authority², 2009}
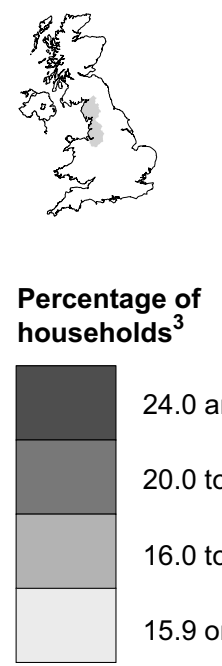

24.0 and over

20.0 to 23.9

16.0 to 19.9

15.9 or under

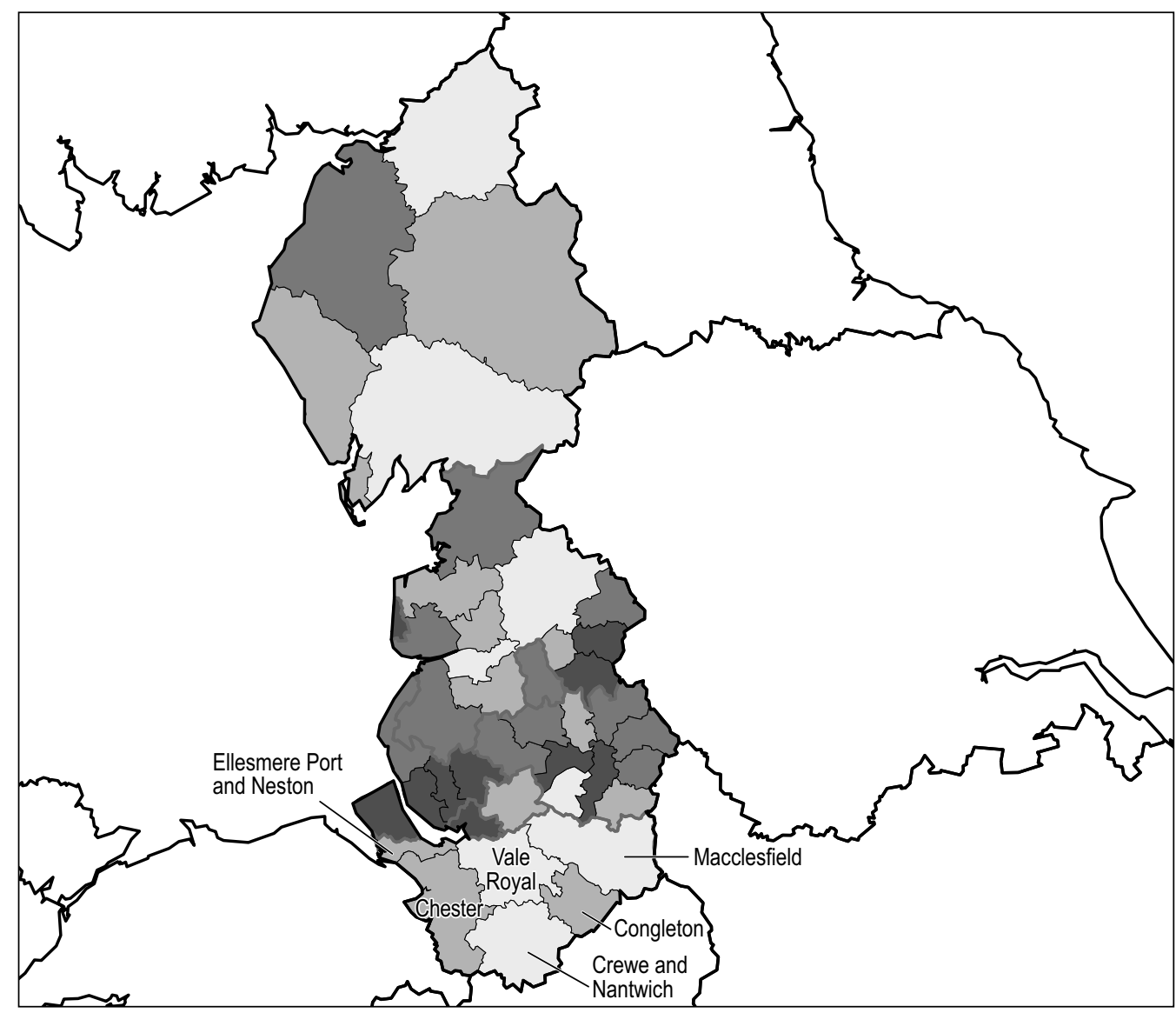

(c) Crown copyright and database right 2011. Ordnance Survey Licence 100019153.

1 A workless household is one which contains at least one person aged 16 to 64 where no-one aged 16 or over is in employment.

2 This map shows pre-April 2009 local and unitary authorities in Cheshire. For key to areas not named on the map, see Map 2.

3 Households including at least one person aged 16-64.

Source: Annual Population Survey, Office for National Statistics

\section{Health}

For males and females, life expectancy in the North West was approximately one year below the UK equivalent, although the North West life expectancy was one year higher than in 2003-05. In 2007-09, male life expectancy at birth in the North West was 76.6 years compared with 77.9 in the UK. This was among the lowest in the UK, similar to the North East and Northern Ireland but above Scotland. For females, life expectancy at birth was 80.8 years compared with 82.0 in the UK (see Figure 19). 


\section{Figure 19 Life expectancy at birth: by sex, country and region}

United Kingdom, 2007-2009

Difference in years from the UK average

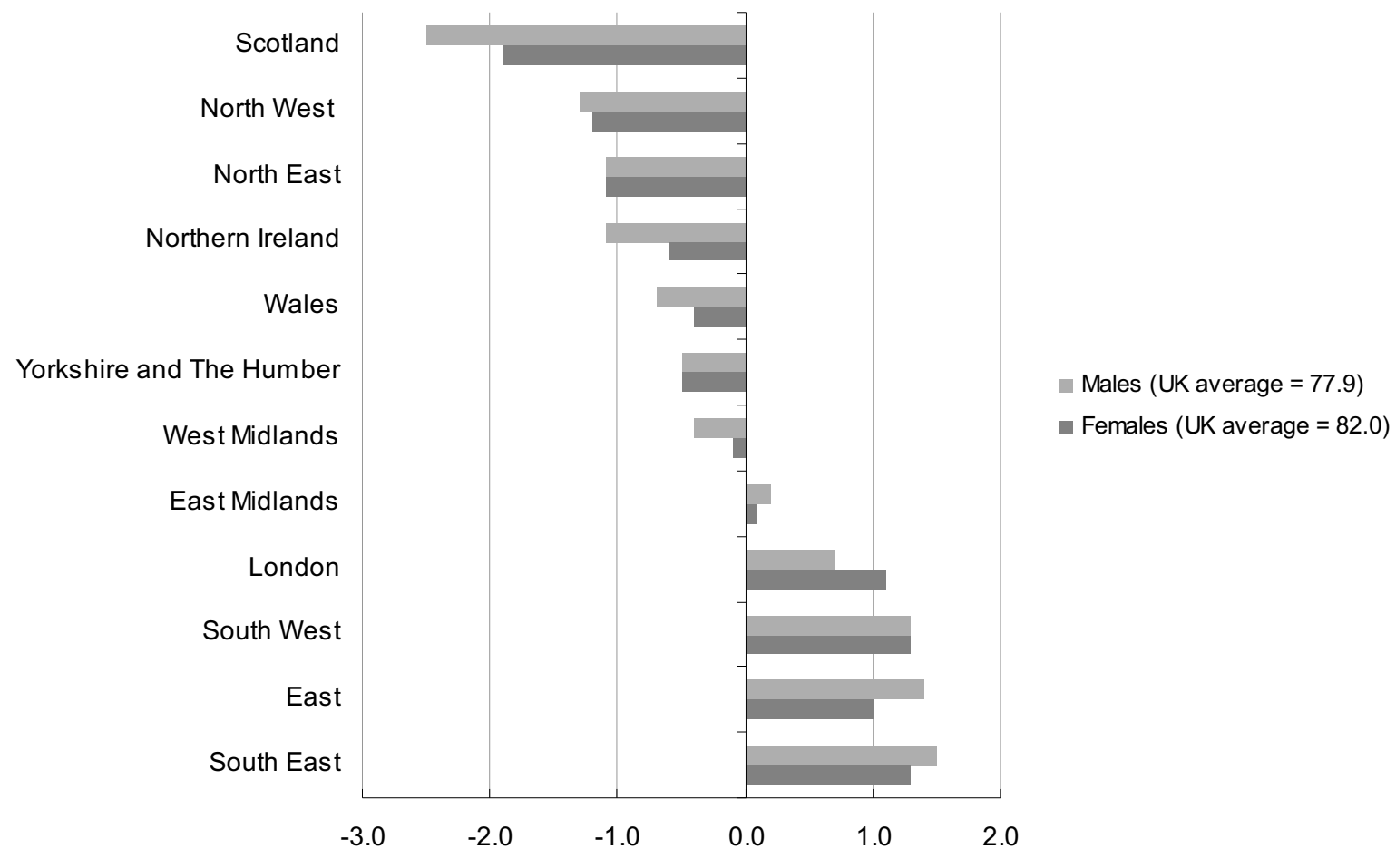

Source: Office for National Statistics

Among North West counties and unitary authorities, life expectancy at birth in 2007-2009 ranged from 73.7 years in Blackpool to 79.5 years in Eden for males, and from 79.1 years in Manchester (district) to 83.3 years in Eden for females.

Age-standardised mortality rates for the region show 656 deaths per 100,000 residents in 2008, compared with 592 for the UK. The North West's mortality rate was one of the highest of the English regions, behind the North East; it was also higher than Wales and Northern Ireland but lower than Scotland. In 2008 the North West had the highest mortality rate for respiratory diseases of all English regions and countries in the UK. Death rates for ages up to 44 were similar to the UK, but for ages over 44 years the North West's death rate was higher than the UK equivalent.

Conception rates for women aged under 18 were higher in the North West than across England in 2008 (46 per 1,000 women aged 15 to 17 compared with 40 nationally). The proportion of under-18 conceptions that led to a legal abortion was 49 per cent, which is slightly lower than England (50 per cent). Within the region it varied from 41 per cent in Salford and Blackpool to 60 per cent in Trafford.

The North West had an infant mortality rate of 5.2 per 1,000 live births in 2008 , compared with 4.7 nationally. The North West region's proportion of live births weighing less than $2.5 \mathrm{~kg}$ in 2008 was 7.3 per cent, slightly above 7.2 per cent for England. Within the region this varied from 10.0 per cent in Preston to 4.6 per cent in South Lakeland. 
The average incidence of alcohol consumption among adults in the North West was close to the Great Britain average in 2008, with 63 per cent drinking at least once in the previous week compared with 62 per cent nationally. Only 13 per cent of North West adults drank on five or more days in the previous week, compared with the Great Britain average of 15 per cent (Figure 20). However, the average weekly alcohol consumption in the North West in 2008 was 13.5 units compared with 12.2 nationally.

\section{Figure 20 Alcohol drunk on 5 or more days in week: by sex ${ }^{1}$, country and region}

United Kingdom, 2008

Percentages

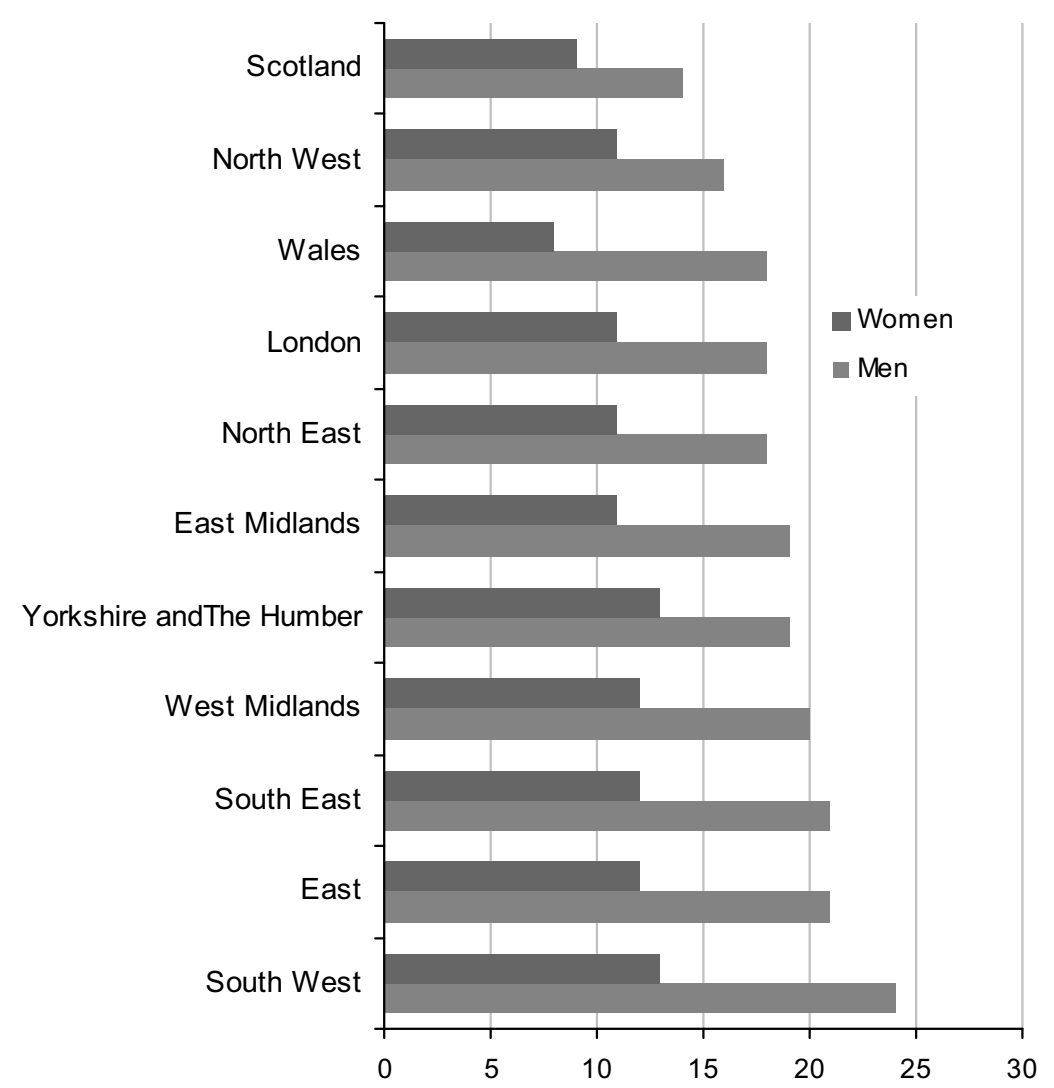

1 Men and women aged 16 and over

Source: General Lifestyle Survey, Office for National Statistics

Cigarette smoking was also close to the national average. In the North West 25 per cent of men smoked cigarettes in 2007, slightly above the average of 22 per cent for Great Britain. Among women 22 per cent smoked cigarettes, almost identical to the Great Britain figure of 21 per cent. About 26 per cent of adults in the region were non-smokers who had been regular smokers, very close to the Great Britain figure of 25 per cent.

According to the 2009/10 British Crime Survey, about 10 per cent of 16 to 59-year-olds in the North West reported that they had used drugs in the previous year. This was the highest proportion of all the regions in England and Wales. The North West had the second highest proportion of people who stated that they had used a Class A drug (4.0 per cent compared with 3.1 per cent across 
England and Wales) and the highest proportion of people using a stimulant drug. This is above the England and Wales figure of 3.7.

\section{Transport}

According to the National Travel Survey, in 2007 to 2008 the average North West resident made around 980 journeys within Great Britain each year. Yorkshire and The Humber, and London were the only English regions where residents made fewer journeys than the North West. About 31 per cent of the North West journeys were for leisure purposes, 20 per cent were for shopping and 16 per cent were commuting journeys, all similar proportions to the national equivalents.

\section{Figure $21 \quad$ Usual method of travel to work: by mode of transport, and country or region of residence}

United Kingdom, 2008 Q4

Percentages

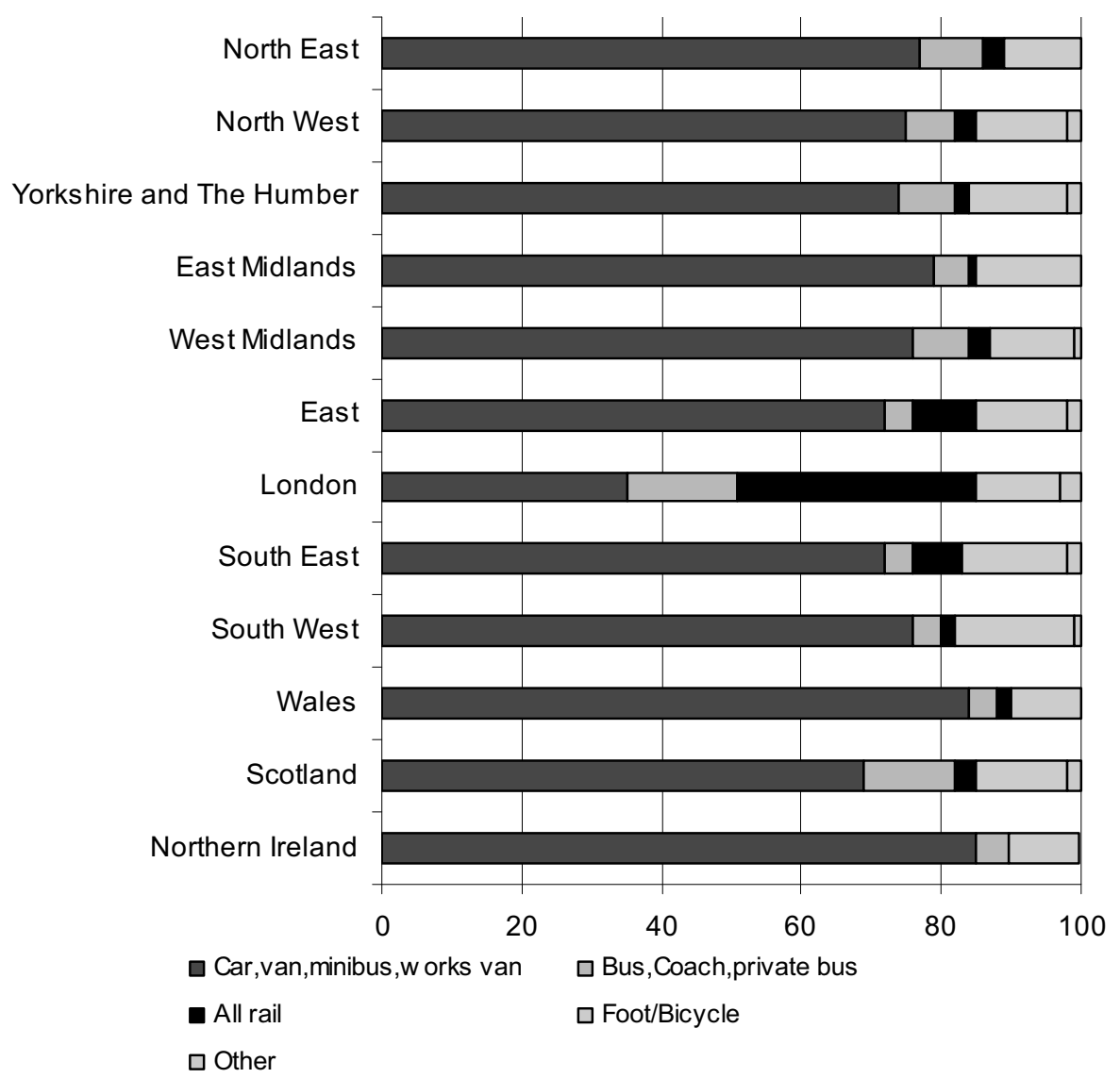

Source: Labour Force Survey, Office for National Statistics

In 2007 to 2008, the average distance travelled per person per year in the North West by all modes of transport was relatively low at 6,400 miles. This is similar to the North East but not as low as London residents, who travelled the smallest distance, 5,300 miles. In the North West, over 5,200 
miles (84 per cent) were undertaken as a car driver or passenger or by other private road vehicle, similar to the Great Britain average of 81 per cent.

In the last quarter of 2008,75 per cent of journeys to work (excluding those working at home) were by car or van, a larger percentage than the England average (69 per cent) (see Figure 21). The proportion of such journeys made on foot or bicycle (13 per cent) was similar to the England average (14 per cent) but a lower proportion was made by public transport (10 per cent and 15 per cent respectively). In 2007, 61 per cent of journeys to work in the North West took 20 minutes or less, compared with 56 per cent for England.

The proportion of 5 to 16-year-olds resident in the region who walked to school in 2007 to 2008 was 45 per cent and the proportion going to school in cars was 31 per cent, both the same as the average for Great Britain. The average journey distance to school was 1.3 miles for 5 to 10 -yearolds, which was one of the shortest of all the regions of England and below the average for Great Britain of 1.6 miles. For 11 to 16 -year-olds it was 3.0 miles, close to the Great Britain average of 3.2 miles.

The increasing dependence on cars is evident in the increase in the volume of traffic on the region's major roads of 10 per cent in the ten years to 2008, slightly above the 9 per cent increase for England. In the North West 47 per cent of motor vehicle traffic on major roads was on motorways; this is highest proportion of all English regions and well above the Great Britain average of 31 per cent. With over 20,000 accidents in 2008, the North West's roads are among the most dangerous in the country. Relative to the volume of traffic, the accident rate on major roads was the highest outside London at 275 per billion vehicle kilometres, compared with the average of 260 for Great Britain.

\section{Environment}

National Park land in the North West amounts to 2,620 sq km. This represents 18 per cent of the region's land area, compared with an England figure of 9 per cent. A further 11 per cent of the region's land is designated as Areas of Outstanding Natural Beauty (AONB), compared with 15 per cent for England. The North West has one of the highest proportions of its land area designated as Green Belt land, 19 per cent compared with 13 per cent for England. The North West also has 18 per cent of its area designated as Sites of Special Scientific Interest (SSSI's).

The latest long-term climate averages indicate that the North West region as originally designated by the former National Rivers Authority (NRA - now part of the Environment Agency) had a long term average annual rainfall of 1,176 millilitres between 1971 and 2000 . This is higher than the England average of 819 millilitres, similar to the UK average $(1,084 \mathrm{~mm})$ and the figures for the South West and Northern Ireland, but lower than those for Wales and Scotland. In 2010, the North West had annual rainfall of over 980 millilitres, lower than the long-term average but still second highest in England.

In 2008 the Environment Agency estimated that almost 29,000 North West properties were at significant risk of flooding from rivers or the sea, 6 per cent of the total in England and the third 
lowest regional total. Over a fifth of these properties $(6,500)$ are in Warrington, the only area in the North West to be within the top 10 local areas with the highest number of properties in areas with a significant chance of flooding from rivers or the sea.

Almost 64 per cent of rivers in the North West were of good biological quality in 2007, one of the lowest proportions in England. However, over 82 per cent were of good chemical quality, the second highest in England.

\section{Figure 22 Installed capacity of sites generating electricity from wind and waves: by region}

England, 2009

Megawatts

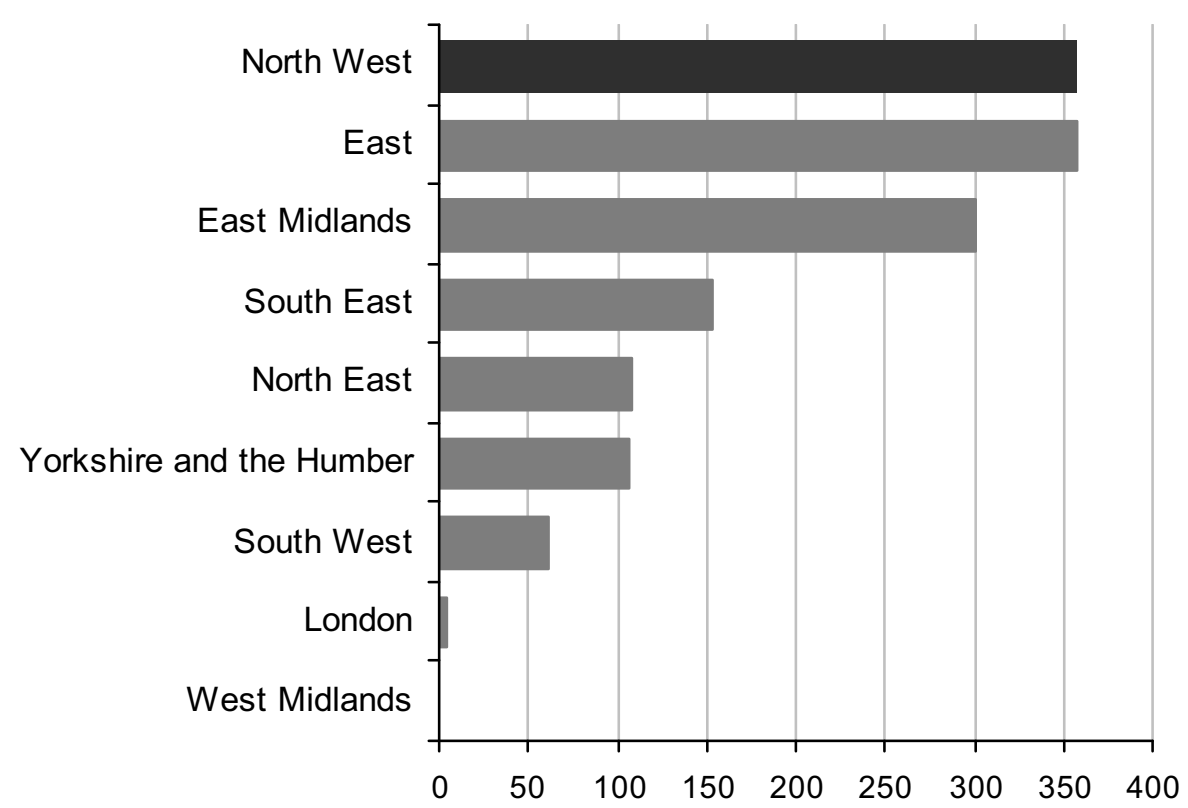

Source: Department of Energy and Climate Change

Of the 939 sites in England generating electricity from renewable sources in 2009, 150 were in the North West (16 per cent) - more than any other English region. The region had the second greatest capacity to generate electricity from renewable sources (573 megawatts), 62 per cent of which was from wind and waves (See Figure 22). The region actually generated more electricity from wind and waves (904 gigawatt hours) than any other region, contributing 30 per cent of the total for England.

Carbon dioxide $\left(\mathrm{CO}_{2}\right)$ emissions in the North West totalled 57,400 kilotonnes in 2008 , around 11.3 per cent of the UK total, the second largest total behind the South East (63,800 kilotonnes). This was approximately 800 kilotonnes less than in 2007 , a 1.3 per cent fall that is lower than the 2.2 per cent decrease for the UK. Industrial and commercial users were responsible for 44 per cent of these emissions, a slightly lower proportion than nationally (45 per cent). The North West total equates to 8.3 tonnes of $\mathrm{CO}_{2}$ per person in 2008, close to the UK figure of 8.2 tonnes per person. 
North West residents had the second highest levels of residual household waste of the nine English regions in 2009/10, $658 \mathrm{~kg}$ per household. In the previous five years this figure has fallen 35 per cent. Over the same period, the household recycling rate for the North West rose from 19 per cent to 39 per cent, compared with an average of 40 per cent for England in 2009/10.

\section{Crime}

British Crime Survey (BCS) data show that the North West household crime rate of 2,700 per 10,000 households in 2009/10 was the third highest of all English regions, above the England average of 2,600 per 10,000 (Figure 23). The risk of being a victim of household crime at least once in the North West was 17 per cent, the same as nationally. However, there is significant variation within the region: there was a 21 per cent risk of being a victim of household crime at least once in Greater Manchester compared with 12 per cent in Merseyside, which is a significantly lower than risk than in 2008/09.

\section{Figure 23 Crimes committed against households: by region}

England, 2009/10

Rate per 10,000 households

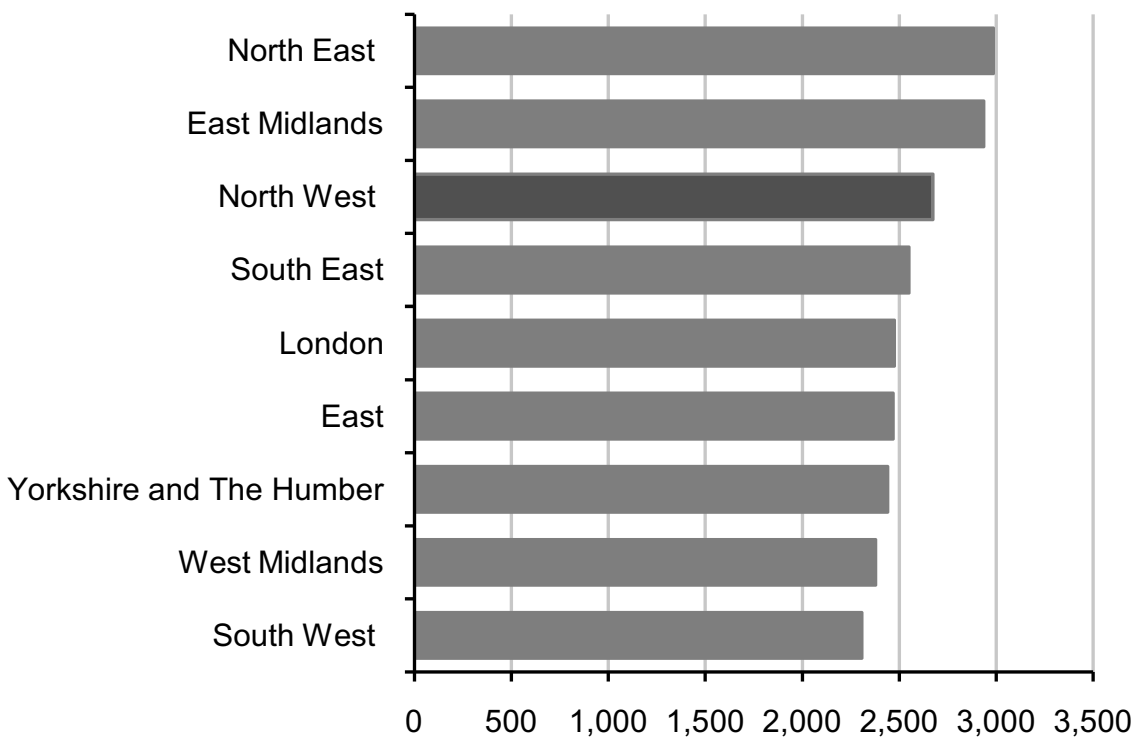

Note: England rate $=2,550$

Source: British Crime Survey, Home Office

The rate of crimes against the person in the region is similar to the England equivalent, around 845 per 10,000 adults in $2009 / 10$ compared with 820 per 10,000 adults in England. 
Responses to the 2009/10 BCS also show that in the North West 29 per cent thought that there was a problem with drug use or dealing, significantly higher than the national average (26 per cent). This was concentrated in Greater Manchester and Merseyside. However, the perception of this type of behaviour was significantly lower than in 2008/09.

The North West recorded crime rate in 2009/10 was also the third highest at 8,100 per 100,000 population compared with the England average of 7,900. However, the rate for drugs and other offences was second highest, working out at nearly 7 crimes per 1,000 people compared with around 10 per 1,000 in London.

The detection rate for recorded crimes (the ratio of offences cleared up in the year to offences recorded in the year) was 30 per cent in the North West in 2009/10. This was the third highest among the English regions compared with the England average of 27 per cent. There was a significant variation in the region between offence groups; detection rates were 95 per cent for drug offences compared with offence against vehicles at 12 per cent.

In 2007 the rates of conviction in the North West were among the highest of all English regions, at 1,000 per 100,000 population for the 18 and over age group, compared with an England average of 700 . In the 10 to 17 age group the rate of conviction in the North West was 1,400 per 100,000 population, second to the North East rate of 1,700 per 100,000 population, compared with the England average of 1,200.

The March 2009 police service strength of 20,000 officers on ordinary duty corresponded to 1 officer to 350 people in the region. This was fewer residents per police officer than the England average of 380 . The North West had a smaller ratio of special constables than England, 79 per 1,000 police officers compared with 99 per 1,000 across England.

\section{Notes}

1. The authors wish to thank colleagues in the Centre for Regional and Local Statistics and the Mapping Unit in the Office for National Statistics (ONS) for help in producing this article.

2. The Glossary and Regional Trends Online Tables, where much of the data used in this article may be downloaded, are available through links at: www.statistics.gov.uk/regionaltrends/editions 